University of Nebraska - Lincoln

DigitalCommons@University of Nebraska - Lincoln

1992

\title{
Stable Isotope Study of Water-Rock Interaction and Ore Formation, Bayhorse Base and Precious Metal District, Idaho
}

Robert R. Seal II

U.S. Geological Survey, 954 National Center, Reston, Virginia 20192, USA, rseal@usgs.gov

Robert O. Rye

USGS

Follow this and additional works at: https://digitalcommons.unl.edu/usgsstaffpub

Part of the Earth Sciences Commons

Seal, Robert R. II and Rye, Robert O., "Stable Isotope Study of Water-Rock Interaction and Ore Formation, Bayhorse Base and Precious Metal District, Idaho" (1992). USGS Staff -- Published Research. 342.

https://digitalcommons.unl.edu/usgsstaffpub/342

This Article is brought to you for free and open access by the US Geological Survey at DigitalCommons@University of Nebraska - Lincoln. It has been accepted for inclusion in USGS Staff -- Published Research by an authorized administrator of DigitalCommons@University of Nebraska - Lincoln. 


\title{
Stable Isotope Study of Water-Rock Interaction and Ore Formation, Bayhorse Base and Precious Metal District, Idaho
}

\author{
ROBERT R. SEAL II \\ U. S. Geological Survey, 954 National Center, Reston, Virginia 22092 \\ AND ROBERT O. RYE \\ U. S. Geological Survey, 963 Denver Federal Center, Denver, Colorado 80225
}

\begin{abstract}
The Bayhorse base and precious metal district is situated east of the Idaho batholith in south-central Idaho. The ores occur near the Nevada Mountain granitic stock as veins cutting the lower Paleozoic Ramshorn Slate and the Garden Creek Phyllite, and as fillings around breccia fragments within the Bayhorse Dolomite. The veins are dominated by siderite and tetrahedrite, with lesser quartz and galena, whereas the breccia ores dominantly comprise only quartz and galena. Mineralization and intrusive activity were contemporaneous during Cretaceous time. Fluid inclusion and stable isotope data indicate that mineralization formed from hot (ca. $\left.375^{\circ}-225^{\circ} \mathrm{C}\right), \mathrm{CO}_{2}$-rich $(\leq 8.3 \pm 1.4$ mole $\%)$ brines $(5-20 \mathrm{wt} \% \mathrm{NaCl}$ equiv) at confining pressures between 1.1 and 1.7 kbars. Fluid cooling and the resulting $\mathrm{CO}_{2}$ effervescence were the most important causes of ore deposition.

Whole-rock $\delta^{18} \mathrm{O}$ and $\delta \mathrm{D}$ values from the Garden Creek Phyllite define an isotopically depleted zone $\left(60 \mathrm{~km}^{2}\right)$ around the Nevada Mountain stock and are the result of high-temperature interactions with ancient meteoric waters at water/rock ratios (mass fractions) ranging from 0.002 to 0.09 . The $\delta^{18} \mathrm{O}_{\mathrm{H}_{2} \mathrm{O}}$ and $\delta \mathrm{D}_{\mathrm{H}_{2} \mathrm{O}}$ values of the ore fluids ranged from 11.2 to 3.9 per mil and from -55 to -146 per mil, respectively. Comparison of the ore fluid $\delta^{18} \mathrm{O}_{\mathrm{H}_{2} \mathrm{O}}$ and $\delta \mathrm{D}_{\mathrm{H}_{2} \mathrm{O}}$ values with hypothetical waters equilibrated with the Garden Creek Phyllite indicates that the hydrothermal fluids must have also interacted with the basal dolomite of Bayhorse Creek, which underlies the phyllite. Early $\delta^{13} \mathrm{C}_{\mathrm{CO}_{2}}$ values calculated in equilibrium with siderite ranged from -9.1 to -7.4 per mil, whereas later $\delta^{13} \mathrm{C}_{\mathrm{CO}_{2}}$ values obtained from quartzhosted fluid inclusion extracts range from -4.0 to -1.8 per mil. The $\delta^{13} \mathrm{C}_{\mathrm{CO}_{2}}$ values for the hydrothermal fluids thus also record a transition from early water/rock interactions that were dominated by the Garden Creek Phyllite (organic matter $\delta^{13} \mathrm{C}=-23.6$ to $-20.9 \%$ ) to later interactions that were influenced significantly by the basal dolomite of Bayhorse Creek $\left(\delta^{13} \mathrm{C}\right.$ $=-2.3$ to $-2.2 \%$ ) . The $\delta^{34} \mathrm{~S}$ values of main-stage hydrothermal sulfides range from 3.0 to 28.3 per mil and display a distinct mode at approximately 10 per mil. The range of values may be interpreted as either a heterogeneous sedimentary source or mixed sedimentary-magmatic sources. On the basis of mass balance considerations, it is likely that all of the fluid salinity and the dissolved metals were derived from the Garden Creek Phyllite. The paragenetic sequence developed in the ores appears to be related to: (1) processes at the site of deposition, most notably cooling and $\mathrm{CO}_{2}$ effervescence, and (2) water-rock interactions within the Garden Creek Phyllite in the $60-\mathrm{km}^{2}$ isotopically altered area surrounding the Nevada Mountain stock.
\end{abstract}

\section{Introduction}

THE relative roles of meteoric and magmatic waters in ancient and modern hydrothermal systems have been the focus of numerous studies, particularly with the development of stable isotope geochemistry as a powerful tracer of ore fluid evolution. It is now generally recognized that hydrothermal systems associated with shallow-level intrusions can be of magmatic, meteoric, or mixed origins. The present study deals with a meteoric water-dominated system and examines the role of water-rock interactions in generating an ore-forming system. Studies of such fossil meteoric water-dominated systems have followed two subpar- allel paths. One approach has studied regional isotopic alteration patterns in country rocks surrounding shallow-level intrusions and has interpreted these patterns in terms of interactions with altering hydrothermal fluids (Criss and Taylor, 1986; Criss and Fleck, 1990). The other approach has studied the isotopic evolution of ore fluids from specific ore deposits and interpreted the evolution of ore fluids in terms of interactions between the hydrothermal solutions and country rocks (Ohmoto and Rye, 1974; Taylor, 1979; Campbell et al., 1984). To date, little effort has united both lines of research. The most notable exception has been the work of Ohmoto et al. 
(1983). The present study seeks to combine both approaches to help quantify the relationship of regional water-rock interactions to ore-forming processes.

The Bayhorse district of south-central Idaho, which has produced over 9 million ounces of silver (Ross, 1937; Chambers, 1966), is well suited for this task because of the small size and the amenability of its orebodies to stable isotope, and to a lesser extent, fluid inclusion studies. The inferred paleolatitude of the district ensures that meteoric waters with isotopic compositions distinctly different from those for magmatic fluids were present. In addition, the isotopically varied metasedimentary carbonates, slates, and phyllites each imparted distinctive isotopic signatures to waters that interacted with them.

\section{Geologic Setting}

The Bayhorse district is located in south-central Idaho, east of the Idaho batholith. The area is dominated by a sequence of lower Paleozoic carbonates and pelites (Hobbs and Hays, 1990) that have been folded into a north-northwest-trending anticline and subsequently intruded by a Cretaceous granodioritic stock (Fig. 1; Ross, 1937; Hodges, 1978; Hobbs, $1985 \mathrm{a}, \mathrm{b})$. The stratigraphically oldest unit in the district is the Cambrian(?) basal dolomite of Bayhorse Creek (>75 m), which is overlain by the Cambrian(?) Garden Creek Phyllite (ca. $230 \mathrm{~m}$ ). The phyllite is dominated by quartz $(60-70 \%)$ and $2 \mathrm{M}_{1}$ muscovite $(30-40 \%)$, with minor amounts of chlorite, $\mathrm{K}$ feldspar, dolomite, siderite, pyrite, chalcopyrite, and organic matter (Seal, 1989). The phyllite grades conformably upward into the Ordovician and/or Cambrian Bayhorse Dolomite (ca. $315 \mathrm{~m}$ ), which has been subdivided into six units on the basis of mineralogic and petrographic criteria (Snyder, 1978). The lowermost unit consists of shaly limestones (unit 1), which grade upward into interbedded limestones and dolomites (units 2 to 4 ). These are followed by massive dolomites (units 5 and 6 ). Unconformably atop the Bayhorse Dolomite is the Ordovician Ramshorn Slate $(>600 \mathrm{~m})$, which comprises metamorphosed shales, siltstones, sandstones, and locally developed conglomerates. The slate is composed of quartz (40$60 \%)$, chlorite $(5-40 \%)$, and $2 \mathrm{M}_{1}$ muscovite (20$60 \%)$, with lesser amounts of $\mathrm{K}$ feldspar. Within the contact aureole of the Nevada Mountain stock, biotite, cordierite, and andalusite are important constituents of the Ramshorn Slate.

The intrusive complex of Nevada Mountain formed at $98 \pm 3 \mathrm{Ma}$ (recalculated from McIntyre et al., 1976 , using revised IUGS constants) and can be divided into three phases: a quartz diorite, a granodiorite, and a quartz-feldspar porphyry (Hodges, 1978). The quartz diorite and the granodiorite contain varying amounts of quartz, plagioclase, $\mathrm{K}$ feldspar, biotite, and hornblende with accessory magnetite, tita-

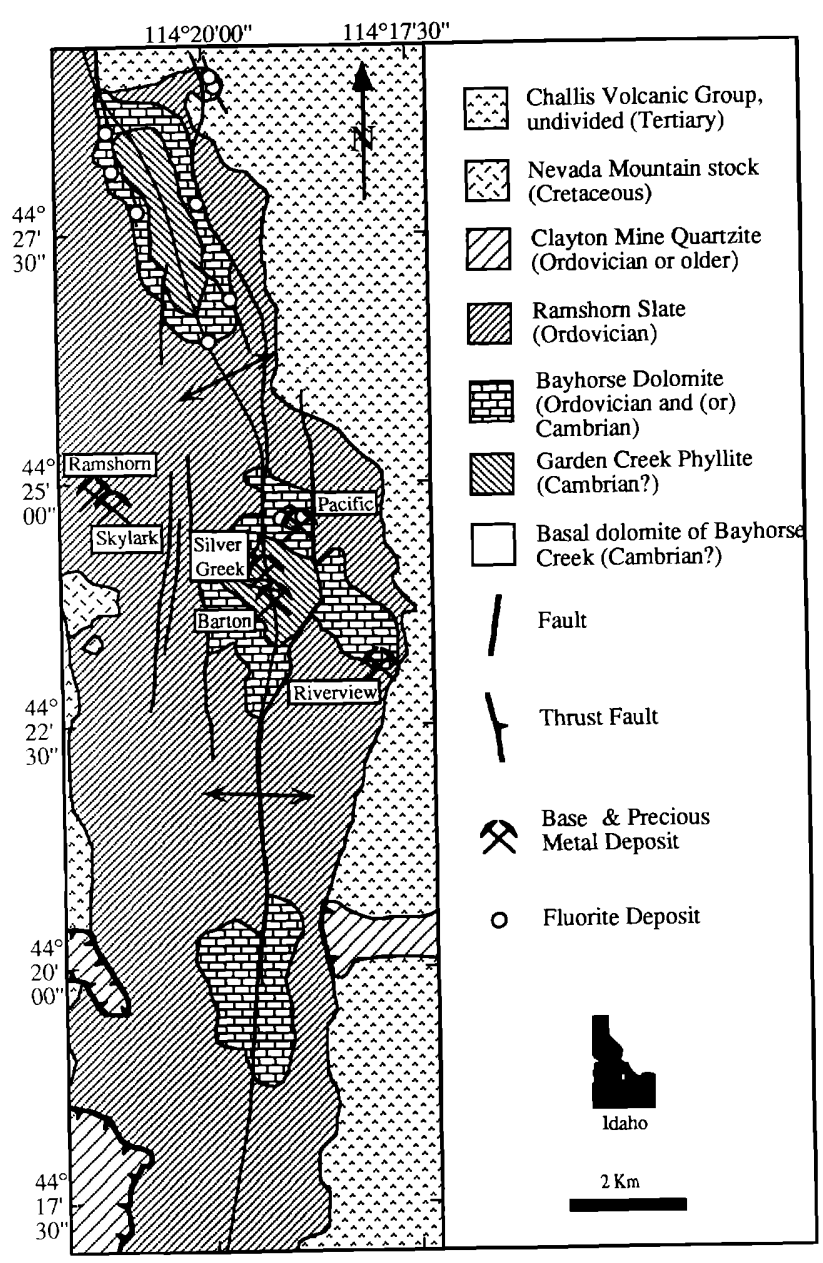

FIG. I. Location, geology, stratigraphy, and ore deposits of the Bayhorse district. Adapted from Hobbs (1985a, b) and Hobbs and Hays (1990).

nite, zircon, and apatite. The quartz-feldspar porphyry, which has been observed only in drill cores, contains quartz and feldspar phenocrysts in a siliceous groundmass and is highly altered (Hodges, 1978).

Penetrative deformation that accompanied the formation of the Bayhorse anticline predated the emplacement of the Nevada Mountain intrusive complex and produced a distinct north-south axial planar cleavage in both the Ramshorn Slate and Garden Creek Phyllite. The area was overlain during Eocene time (51-50 Ma, recalculated from McIntyre et al., 1976 , using revised decay constants) by the Challis Volcanic Group.

\section{Ore Deposits}

\section{Deposit types}

Three main types of mineralization are found in the study area: pelite-hosted siderite-tetrahedrite veins, 
carbonate-hosted $\mathrm{Pb}-\mathrm{Zn}$-Ag deposits, and carbonatehosted fluorite mineralization (Fig. 1). The economically most important siderite-tetrahedrite veins in the district are found in the Ramshorn and Skylark mines which are hosted by the Ramshorn Slate. These vein systems strike north-south and dip to the west. The dip of the Ramshorn vein system varies from $40^{\circ}$ to $70^{\circ} \mathrm{W}$; the Skylark dips between $10^{\circ}$ and $20^{\circ} \mathrm{W}$. Veins range up to $2 \mathrm{~m}$ wide (Ross, 1937). The Ramshorn-Skylark vein system is dominated by early siderite $\left(\mathrm{Fe}_{0.85} \mathrm{Mn}_{0.10} \mathrm{Mg}_{0.05} \mathrm{CO}_{3}\right.$, avg) and minor quartz, followed by tetrahedrite, then quartz and galena. Pyrite, sphalerite, chalcopyrite, and arsenopyrite are found as minor phases (Seal et al., 1990). Wall-rock alteration associated with all veins is minor (Hodges, 1978). Beneath the Ramshorn system, within the Bayhorse Dolomite, drilling encountered a zone of hydrothermal siderite of unknown extent (D. P. Wheeler, pers. commun., 1985). The Barton and Silver Creek deposits, hosted by the Garden Creek Phyllite, are mineralogically similar to the Ramshorn-Skylark veins but contain a greater abundance of quartz.

The carbonate-hosted $\mathrm{Pb}-\mathrm{Zn}$-Ag deposits occur in the upper portions of the Bayhorse Dolomite (units 5 and 6), the most notable of which are the Pacific and Riverview mines. The deposits fill in stratiform and strata-bound breccias where they are transected by high-angle north-south-trending faults (Chambers, 1966). The open spaces surrounding the breccia fragments were filled by quartz, followed by galena and sphalerite. Hobbs (1985a) and Hobbs and Hays (1990) suggested that the breccias were the result of paleokarstic processes during the lower Paleozoic.

The fluorite mineralization formed during the Eocene (McInyre et al., 1976) as breccia and vein fillings and was genetically unrelated to the older base and precious metal mineralization (Snyder, 1978; Constantopoulos, 1988; Seal and Rye, 1991). Fluorite mineralization locally invaded previously mineralized zones of base and precious metals (Snyder, 1978).

\section{Age relations and paragenesis}

A two-stage districtwide paragenetic sequence can be defined for the deposits of the study area. The earlier stage I association is characterized by siderite, tetrahedrite, and minor quartz. The later stage II association consists of abundant quartz and galena, with lesser tetrahedrite and sphalerite. The entire paragenesis is recorded in the vein deposits, whereas only stage II is found in the carbonate-hosted breccias. At present, the reason for the absence of stage $I$ in the carbonate-hosted ores is unclear and difficult to assess due to the lack of experimental data pertaining to the solubility of tetrahedrite.

Published K-Ar ages for biotite from the Nevada
Mountain stock (98 $\pm 3 \mathrm{Ma})$ and for sericite from an altered vein selvage from the Ramshorn-Skylark vein system $(95 \pm 3 \mathrm{Ma})$ indicate that mineralization was temporally associated with intrusive activity (McIntyre et al., 1976). The fluorite mineralization formed between $51 \pm 2$ and $50 \pm 2 \mathrm{Ma}$ (recalculated from McIntyre et al., 1976, using revised decay constants).

\section{Analytical Methods}

\section{Fluid inclusions}

Fluid inclusion data were obtained by microthermometric heating and freezing, using standard techniques described by Roedder (1984). The analyses were performed on a U.S.G.S. heating and freezing stage. The thermocouple was calibrated against synthetic fluid inclusions (Sterner and Bodnar, 1984) at $-56.6^{\circ}\left(\mathrm{CO}_{2}-\mathrm{H}_{2} \mathrm{O}\right)$ and $-20.0^{\circ} \mathrm{C}\left(\mathrm{H}_{2} \mathrm{O}-\mathrm{NaCl}\right)$, against ice water at $0^{\circ} \mathrm{C}$, and against melting point standards at various temperatures up to $300^{\circ} \mathrm{C}$.

\section{Stable isotopes}

Silicates were analyzed for $\delta^{18} \mathrm{O}$ by extracting oxygen using $\mathrm{BrF}_{5}$ and converting it to $\mathrm{CO}_{2}$ for analysis (Clayton and Mayeda, 1963). Hydrogen was extracted from whole-rock samples for analysis by dehydrating whole-rock samples under vacuum with an induction furnace and converting the evolved water to hydrogen gas by reaction with uranium at $850^{\circ} \mathrm{C}$ (Godfrey, 1962). Carbon dioxide was liberated from the carbonates for $\delta^{18} \mathrm{O}$ and $\delta^{13} \mathrm{C}$ analyses by reaction with phosphoric acid at $25^{\circ} \mathrm{C}$ for calcites and dolomites and at $50^{\circ} \mathrm{C}$ for siderites (McCrea, 1950). The $\delta \mathbf{D}_{\mathrm{H}_{2} \mathrm{O}}$ values for hydrothermal fluids associated with quartz and siderite were determined from fluid inclusion extracts, with procedures described by Rye (1966). The $\delta^{18} \mathrm{O}_{\mathrm{H}_{2} \mathrm{O}}$ values were calculated with fluid inclusion and/or sulfur isotope temperatures combined with published mineral-water fractionation factors (Clayton et al., 1972; Carothers et al., 1988) and mineral $\delta^{18} \mathrm{O}$ values. The $\delta^{18} \mathrm{O}_{\mathrm{H}_{2} \mathrm{O}}$ and $\delta \mathrm{D}_{\mathrm{H}_{2} \mathrm{O}}$ values of fluid inclusion extracts were determined with the $\mathrm{CO}_{2}-\mathrm{H}_{2} \mathrm{O}$ equilibration and uranium reduction technique of Kishima and Sakai (1980). Whenever yields were sufficient, the $\mathrm{CO}_{2}$ liberated during extraction of inclusion fluids was analyzed for both $\delta^{18} \mathrm{O}$ and $\delta^{13} \mathrm{C}$. Tetrahedrite and country-rock pyrite samples were converted to $\mathrm{Ag}_{2} \mathrm{~S}$ prior to conversion to $\mathrm{SO}_{2}$. All other sulfides were converted directly to $\mathrm{SO}_{2}$ for $\delta^{34} \mathrm{~S}$ analysis.

Carbon and oxygen isotope analyses were performed on a Finnigan MAT 251 mass spectrometer. The hydrogen isotope analyses were conducted on a Nuclide 3-60-SECTOR mass spectrometer. Sulfur isotope analyses were done on a Nuclide 6-60-RMS mass spectrometer. All results are reported in stan$\operatorname{dard} \delta$ notation. Oxygen and hydrogen values are re- 
TABLE 1. Carbon and Oxygen Isotope Values (\%) for the Bayhorse Dolomite and the Basal Dolomite of Bayhorse Creek and Carbon Isotope Values (\%) for Organic Matter from the Garden Creek Phyllite

\begin{tabular}{|c|c|c|c|c|}
\hline Sample no. & Unit & $\delta^{13} \mathrm{C}_{\mathrm{PDB}}$ & $\delta^{18} \mathrm{O}_{\text {sMow }}$ & Latitude/longitude \\
\hline BYHQ-1 & BD1 & 0.5 & 12.9 & $44^{\circ} 27^{\prime} 28^{\prime \prime} \mathrm{N} / 114^{\circ} 20^{\prime} 16^{\prime \prime} \mathrm{W}$ \\
\hline BYHQ-9A & BD1 & 0.6 & 16.2 & $44^{\circ} 27^{\prime} 13^{\prime \prime} \mathrm{N} / 114^{\circ} 20^{\prime} 57^{\prime \prime} \mathrm{W}$ \\
\hline BYHQ-90 & BD2-4 & 5.7 & 20.0 & $44^{\circ} 26^{\prime} 47^{\prime \prime} \mathrm{N} / 114^{\circ} 20^{\prime} 00^{\prime \prime} \mathrm{W}$ \\
\hline BYHQ-91 & BD5 & 5.8 & 17.5 & $44^{\circ} 26^{\prime} 45^{\prime \prime} \mathrm{N} / 114^{\circ} 19^{\prime} 58^{\prime \prime} \mathrm{W}$ \\
\hline BYHQ-93 & BD6 & 6.2 & 16.7 & $44^{\circ} 26^{\prime} 44^{\prime \prime} \mathrm{N} / 114^{\circ} 19^{\prime} 54^{\prime \prime} \mathrm{W}$ \\
\hline BYHQ-178 & BD1 & 0.7 & 14.0 & $44^{\circ} 22^{\prime} 58^{\prime \prime} \mathrm{N} / 114^{\circ} 19^{\prime} 31^{\prime \prime} \mathrm{W}$ \\
\hline BYHQ-180 & BDl & 0.4 & 15.3 & $44^{\circ} 23^{\prime} 24^{\prime \prime} \mathrm{N} / 114^{\circ} 19^{\prime} 31^{\prime \prime} \mathrm{W}$ \\
\hline BYHQ-195 & BD2-4 & 4.5 & 21.1 & $44^{\circ} 26^{\prime} 48^{\prime \prime} \mathrm{N} / 114^{\circ} 19^{\prime} 55^{\prime \prime} \mathrm{W}$ \\
\hline BYHQ-196 & BD5 & 5.1 & 16.1 & $44^{\circ} 26^{\prime} 46^{\prime \prime} \mathrm{N} / 114^{\circ} 19^{\prime} 54^{\prime \prime} \mathrm{W}$ \\
\hline BYHQ-197 & BD6 & 5.8 & 17.9 & $44^{\circ} 26^{\prime} 46^{\prime \prime} \mathrm{N} / 114^{\circ} 19^{\prime} 48^{\prime \prime} \mathrm{W}$ \\
\hline BYHQ-199 & BD6 & 3.2 & 19.9 & $44^{\circ} 24^{\prime} 08^{\prime \prime} \mathrm{N} / 114^{\circ} 20^{\prime} 25^{\prime \prime} \mathrm{W}$ \\
\hline BYHQ-200 & BD2-4 & 2.1 & 19.1 & $44^{\circ} 24^{\prime} 07^{\prime \prime} \mathrm{N} / 114^{\circ} 20^{\prime} 23^{\prime \prime} \mathrm{W}$ \\
\hline BYHQ-201 & BD1 & 0.5 & 15.9 & $44^{\circ} 24^{\prime} 06^{\prime \prime} \mathrm{N} / 114^{\circ} 20^{\prime} 12^{\prime \prime} \mathrm{W}$ \\
\hline BYHQ-204 & BD2-4 & 2.3 & 19.8 & $44^{\circ} 23^{\prime} 49^{\prime \prime} \mathrm{N} / 114^{\circ} 18^{\prime} 17^{\prime \prime} \mathrm{W}$ \\
\hline BYHQ-205 & BD5 & 4.5 & 16.4 & $44^{\circ} 23^{\prime} 51^{\prime \prime} \mathrm{N} / 114^{\circ} 18^{\prime} 19^{\prime \prime} \mathrm{W}$ \\
\hline BYHQ-206 & BD5 & 6.9 & 17.6 & $44^{\circ} 23^{\prime} 53^{\prime \prime} \mathrm{N} / 114^{\circ} 18^{\prime} 17^{\prime \prime} \mathrm{W}$ \\
\hline BYHQ-207 & BD6 & 7.0 & 16.7 & $44^{\circ} 23^{\prime} 56^{\prime \prime} \mathrm{N} / 114^{\circ} 18^{\prime} 15^{\prime \prime} \mathrm{W}$ \\
\hline BYHQ-208 & BD2-4 & 0.8 & 20.7 & $44^{\circ} 27^{\prime} 37^{\prime \prime} \mathrm{N} / 114^{\circ} 20^{\prime} 18^{\prime \prime} \mathrm{W}$ \\
\hline BYHQ-209 & BD2-4 & 2.3 & 21.2 & $44^{\circ} 27^{\prime} 38^{\prime \prime} \mathrm{N} / 114^{\circ} 20^{\prime} 13^{\prime \prime} \mathrm{W}$ \\
\hline BYHQ-210 & BD6 & 4.6 & 18.0 & $44^{\circ} 27^{\prime} 39^{\prime \prime} \mathrm{N} / 114^{\circ} 20^{\prime} 05^{\prime \prime} \mathrm{W}$ \\
\hline BYHQ-152 & BC & -2.3 & 18.8 & $44^{\circ} 23^{\prime} 56^{\prime \prime} \mathrm{N} / 114^{\circ} 19^{\prime} 02^{\prime \prime} \mathrm{W}$ \\
\hline BYHQ-211 & BC & -2.2 & 20.9 & $44^{\circ} 24^{\prime} 00^{\prime \prime} \mathrm{N} / 114^{\circ} 19^{\prime} 14^{\prime \prime} \mathrm{W}$ \\
\hline BYHQ-7 & GCP & -20.9 & & $44^{\circ} 27^{\prime} 16^{\prime \prime} \mathrm{N} / 114^{\circ} 20^{\prime} 39^{\prime \prime} \mathrm{W}$ \\
\hline BYHQ-154 & GCP & -22.0 & & $44^{\circ} 23^{\prime} 51^{\prime \prime} \mathrm{N} / 114^{\circ} 18^{\prime} 46^{\prime \prime} \mathrm{W}$ \\
\hline BYHQ-174 & GCP & -23.6 & & $44^{\circ} 28^{\prime} 41^{\prime \prime} \mathrm{N} / 114^{\circ} 21^{\prime} 23^{\prime \prime} \mathrm{W}$ \\
\hline
\end{tabular}

Units: BD1 = Bayhorse Dolomite, unit 1; BD2-4 = Bayhorse Dolomite, units 2 to 4 , undivided; BD5 = Bayhorse Dolomite, unit 5; BD6 $=$ Bayhorse Dolomite, unit 6; $\mathrm{BC}=$ basal dolomite of Bayhorse Creek; GCP $=$ Garden Creek Phyllite, organic matter

ported relative to the SMOW standard, carbon relative to PDB, and sulfur relative to CDT. Reproducibility is approximately $\pm 0.1(1 \sigma)$ per mil for oxygen, carbon, and sulfur and $\pm 1(1 \sigma)$ per mil for hydrogen.

\section{Stable Isotope Relationships of the Metasediments}

\section{Carbonate rocks}

The isotopic values for whole-rock samples of the basal dolomite of Bayhorse Creek and the Bayhorse Dolomite range from 12.9 to 21.2 per mil for $\delta^{18} \mathrm{O}$ and from -2.3 to +7.0 per mil for $\delta^{13} \mathrm{C}$ (Table 1). Samples show a marked correlation between $\delta^{13} \mathrm{C}$ and stratigraphic position for both dolomites (Fig. 2). The basal dolomite of Bayhorse Creek and the lowermost part of the Bayhorse Dolomite record $\delta^{13} \mathrm{C}$ values that are typical for lower Paleozoic marine carbonates $(0 \pm 2 \%$; Lohmann, 1988). In contrast, units 5 and 6 and portions of units 2 to 4 of the Bayhorse Dolomite have higher values. The most likely cause of this positive deviation from marine $\delta^{13} \mathrm{C}$ values is diagenetic bacterial fermentation of organic matter that produced isotopically light methane within these horizons (Irwin et al., 1977).

The $\delta^{18} \mathrm{O}$ values of units 2 to 6 of the Bayhorse Dolomite show little variation, whereas those for unit 1 show significant scatter toward lower values, and suggest that unit 1 may have interacted with isotopi- cally light meteoric waters. The lack of systematic regional variations in the whole-rock values indicates that the water-rock interactions were controlled by local permeabilities.

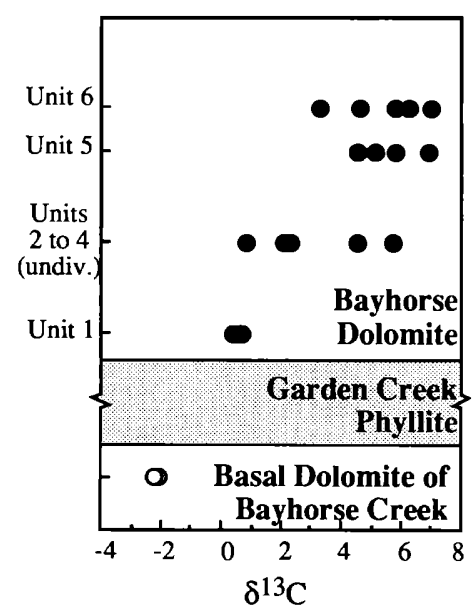

FIG. 2. Stratigraphic variation of $\delta^{13} \mathrm{C}$ values (\%o) for the basal dolomite of Bayhorse Creek and the Bayhorse Dolomite. Stratigraphic units are designated on the ordinate by unit numbers for the Bayhorse Dolomite (Snyder, 1978). Solid symbols = the Bayhorse Dolomite and open symbols = the basal dolomite of Bayhorse Creek. 


\section{Pelitic rocks}

Whole-rock $\delta^{18} \mathrm{O}$ values for the Ramshorn Slate range from 10.0 to 12.6 per mil (Table 2) and exhibit a positive skewness (Fig. 3a). This asymmetric popula-

TABLE 2. Whole-Rock Oxygen and Hydrogen Isotope Values $(\%)$ for the Ramshorn Slate and Garden Creek Phyllite

\begin{tabular}{|c|c|c|c|}
\hline Sample no. & $\delta^{18} \mathrm{O}_{\text {SMOW }}$ & $\delta \mathrm{D}_{\text {SMOW }}$ & Latitude/longitude \\
\hline \multicolumn{4}{|c|}{ Ramshorn Slate } \\
\hline BDMQ-4 & 12.0 & & $44^{\circ} 22^{\prime} 08^{\prime \prime} \mathrm{N} / 114^{\circ} 20^{\prime} 07^{\prime \prime} \mathrm{W}$ \\
\hline BDMQ-12 & 12.3 & & $44^{\circ} 17^{\prime} 19^{\prime \prime} \mathrm{N} / 114^{\circ} 18^{\prime} 49^{\prime \prime} \mathrm{W}$ \\
\hline BDMQ-15 & 10.0 & & $44^{\circ} 22^{\prime} 03^{\prime \prime} \mathrm{N} / 114^{\circ} 21^{\prime} 41^{\prime \prime} \mathrm{W}$ \\
\hline BDMQ-16 & 10.8 & & $44^{\circ} 21^{\prime} 45^{\prime \prime} \mathrm{N} / 114^{\circ} 21^{\prime} 22^{\prime \prime} \mathrm{W}$ \\
\hline BDMQ-19 & 11.7 & & $44^{\circ} 21^{\prime} 20^{\prime \prime} \mathrm{N} / 114^{\circ} 20^{\prime} 01^{\prime \prime} \mathrm{W}$ \\
\hline BDMQ-21 & 12.1 & & $44^{\circ} 21^{\prime} 03^{\prime \prime} \mathrm{N} / 114^{\circ} 20^{\prime} 59^{\prime \prime} \mathrm{W}$ \\
\hline BDMQ-22 & 11.6 & & $44^{\circ} 21^{\prime} 06^{\prime \prime} \mathrm{N} / 114^{\circ} 21^{\prime} 21^{\prime \prime} \mathrm{W}$ \\
\hline BDMQ-23 & 10.9 & & $44^{\circ} 20^{\prime} 14^{\prime \prime} \mathrm{N} / 114^{\circ} 21^{\prime} 43^{\prime \prime} \mathrm{W}$ \\
\hline BDMQ-28 & 12.2 & & $44^{\circ} 19^{\prime} 08^{\prime \prime} \mathrm{N} / 114^{\circ} 20^{\prime} 11^{\prime \prime} \mathrm{W}$ \\
\hline BDMQ-30 & 12.4 & & $44^{\circ} 19^{\prime} 13^{\prime \prime} \mathrm{N} / 114^{\circ} 21^{\prime} 23^{\prime \prime} \mathrm{W}$ \\
\hline BYHQ-16 & 12.1 & -71 & $44^{\circ} 27^{\prime} 51^{\prime \prime} \mathrm{N} / 114^{\circ} 21^{\prime} 59^{\prime \prime} \mathrm{W}$ \\
\hline BYHQ-23 & 12.3 & & $44^{\circ} 27^{\prime} 09^{\prime \prime} \mathrm{N} / 114^{\circ} 21^{\prime} 13^{\prime \prime} \mathrm{W}$ \\
\hline BYHQ-38 & 12.2 & & $44^{\circ} 24^{\prime} 09^{\prime \prime} \mathrm{N} / 114^{\circ} 21^{\prime} 20^{\prime \prime} \mathrm{W}$ \\
\hline BYHQ-39 & 11.8 & & $44^{\circ} 24^{\prime} 10^{\prime \prime} \mathrm{N} / 114^{\circ} 21^{\prime} 13^{\prime \prime} \mathrm{W}$ \\
\hline BYHQ-47 & 11.8 & & $44^{\circ} 26^{\prime} 12^{\prime \prime} \mathrm{N} / 114^{\circ} 20^{\prime} 19^{\prime \prime} \mathrm{W}$ \\
\hline BYHQ-59 & 12.5 & & $44^{\circ} 25^{\prime} 54^{\prime \prime} \mathrm{N} / 114^{\circ} 21^{\prime} 18^{\prime \prime} \mathrm{W}$ \\
\hline BYHQ-63 & 12.3 & & $44^{\circ} 26^{\prime} 24^{\prime \prime} \mathrm{N} / 114^{\circ} 21^{\prime} 17^{\prime \prime} \mathrm{W}$ \\
\hline BYHQ-75 & 11.4 & & $44^{\circ} 27^{\prime} 13^{\prime \prime} \mathrm{N} / 114^{\circ} 22^{\prime} 14^{\prime \prime} \mathrm{W}$ \\
\hline BYHQ-100 & 11.6 & & $44^{\circ} 25^{\prime} 10^{\prime \prime} \mathrm{N} / 114^{\circ} 21^{\prime} 33^{\prime \prime} \mathrm{W}$ \\
\hline BYHQ- 103 & 11.6 & & $44^{\circ} 25^{\prime} 32^{\prime \prime} \mathrm{N} / 114^{\circ} 21^{\prime} 20^{\prime \prime} \mathrm{W}$ \\
\hline BYHQ-106 & 12.0 & & $44^{\circ} 25^{\prime} 27^{\prime \prime} \mathrm{N} / 114^{\circ} 21^{\prime} 04^{\prime \prime} \mathrm{W}$ \\
\hline BYHQ-112 & 10.7 & -84 & $44^{\circ} 24^{\prime} 27^{\prime \prime} \mathrm{N} / 114^{\circ} 21^{\prime} 39^{\prime \prime} \mathrm{W}$ \\
\hline BYHQ-113 & 11.6 & & $44^{\circ} 24^{\prime} 31^{\prime \prime} \mathrm{N} / 114^{\circ} 21^{\prime} 38^{\prime \prime} \mathrm{W}$ \\
\hline BYHQ-118 & 12.4 & & $44^{\circ} 25^{\prime} 00^{\prime \prime} \mathrm{N} / 114^{\circ} 21^{\prime} 00^{\prime \prime} \mathrm{W}$ \\
\hline BYHQ-I 20 & 11.7 & & $44^{\circ} 24^{\prime} 59^{\prime \prime} \mathrm{N} / 114^{\circ} 20^{\prime} 33^{\prime \prime} \mathrm{W}$ \\
\hline BYHQ-123 & 12.1 & & $44^{\circ} 24^{\prime} 42^{\prime \prime} \mathrm{N} / 114^{\circ} 20^{\prime} 08^{\prime \prime} \mathrm{W}$ \\
\hline BYH & 11.5 & & $44^{\circ} 24^{\prime} 55^{\prime \prime} \mathrm{N} / 114^{\circ} 21^{\prime} 59^{\prime \prime} \mathrm{W}$ \\
\hline BYHQ-129 & 12.3 & & $44^{\circ} 24^{\prime} 52^{\prime \prime} \mathrm{N} / 114^{\circ} 22^{\prime} 17^{\prime \prime} \mathrm{W}$ \\
\hline BYHC & 12.0 & & $44^{\circ} 24^{\prime} 13^{\prime \prime} \mathrm{N} / 114^{\circ} 21^{\prime} 32^{\prime \prime} \mathrm{W}$ \\
\hline 133 & 11.1 & & $44^{\circ} 24^{\prime} 07^{\prime \prime} \mathrm{N} / 114^{\circ} 21^{\prime} 32^{\prime \prime} \mathrm{W}$ \\
\hline BY & 10.2 & -82 & $44^{\circ} 23^{\prime} 16^{\prime \prime} \mathrm{N} / 114^{\circ} 21^{\prime} 47^{\prime \prime} \mathrm{W}$ \\
\hline BYHQ-147 & 11.9 & & $44^{\circ} 24^{\prime} 27^{\prime \prime} \mathrm{N} / 114^{\circ} 21^{\prime} 26^{\prime \prime} \mathrm{W}$ \\
\hline BYHQ-149 & 11.4 & & $44^{\circ} 24^{\prime} 25^{\prime \prime} \mathrm{N} / 114^{\circ} 21^{\prime} 04^{\prime \prime} \mathrm{W}$ \\
\hline BYHQ-150 & 12.6 & & $44^{\circ} 24^{\prime} 04^{\prime \prime} \mathrm{N} / 114^{\circ} 20^{\prime} 28^{\prime \prime} \mathrm{W}$ \\
\hline BYHQ-182 & 11.8 & & $44^{\circ} 22^{\prime} 38^{\prime \prime} \mathrm{N} / 114^{\circ} 19^{\prime} 06^{\prime \prime} \mathrm{W}$ \\
\hline BYHQ-183 & 12.1 & & $44^{\circ} 22^{\prime} 35^{\prime \prime} \mathrm{N} / 114^{\circ} 20^{\prime} 32^{\prime \prime} \mathrm{W}$ \\
\hline BYHQ-186 & 11.4 & & $44^{\circ} 22^{\prime} 53^{\prime \prime} \mathrm{N} / 114^{\circ} 21^{\prime} 44^{\prime \prime} \mathrm{W}$ \\
\hline BYHQ-190 & 10.7 & & $44^{\circ} 23^{\prime} 31^{\prime \prime} \mathrm{N} / 114^{\circ} 21^{\prime} 04^{\prime \prime} \mathrm{W}$ \\
\hline BYHQ-191 & 12.0 & & $44^{\circ} 25^{\prime} 28^{\prime \prime} \mathrm{N} / 114^{\circ} 20^{\prime} 01^{\prime \prime} \mathrm{W}$ \\
\hline BYHQ-192 & 11.8 & & $44^{\circ} 25^{\prime} 10^{\prime \prime} \mathrm{N} / 114^{\circ} 19^{\prime} 30^{\prime \prime} \mathrm{W}$ \\
\hline BYHQ-193 & 12.0 & & $44^{\circ} 24^{\prime} 45^{\prime \prime} \mathrm{N} / 114^{\circ} 18^{\prime} 28^{\prime \prime} \mathrm{W}$ \\
\hline \multicolumn{4}{|c|}{ Garden Creek Phylite } \\
\hline & 10.5 & 104 & $44^{\circ} 27^{\prime} 26^{\prime \prime} \mathrm{N} / 114^{\circ} 2$ \\
\hline BYHQ-5 & 12.9 & & $44^{\circ} 27^{\prime} 23^{\prime \prime} \mathrm{N} / 114^{\circ} 20^{\prime} 22^{\prime \prime} \mathrm{W}$ \\
\hline BYHQ-6 & 15.1 & & $44^{\circ} 27^{\prime} 20^{\prime \prime} \mathrm{N} / 114^{\circ} 20^{\prime} 30^{\prime \prime} \mathrm{W}$ \\
\hline BYHQ-7 & 13.2 & -108 & $44^{\circ} 27^{\prime} 16^{\prime \prime} \mathrm{N} / 114^{\circ} 20^{\prime} 39^{\prime \prime} \mathrm{W}$ \\
\hline BYHQ-8 & 13.5 & & $44^{\circ} 27^{\prime} 26^{\prime \prime} \mathrm{N} / 114^{\circ} 20^{\prime} 47^{\prime \prime} \mathrm{W}$ \\
\hline & 13.3 & & $44^{\circ} 27^{\prime} 24^{\prime \prime} \mathrm{N} / 114^{\circ} 20^{\prime} 57^{\prime \prime} \mathrm{W}$ \\
\hline BYHC & 11.0 & & $44^{\circ} 23^{\prime} 54^{\prime \prime} \mathrm{N} / 114^{\circ} 18^{\prime} 52^{\prime \prime} \mathrm{W}$ \\
\hline BYHC & 10.0 & -106 & $44^{\circ} 23^{\prime} 51^{\prime \prime} \mathrm{N} / 114^{\circ} 18^{\prime} 46^{\prime \prime} \mathrm{W}$ \\
\hline BYHQ-174 & 14.3 & -67 & $44^{\circ} 28^{\prime} 41^{\prime \prime} \mathrm{N} / 114^{\circ} 21^{\prime} 23^{\prime \prime} \mathrm{W}$ \\
\hline BYHQ-175 & 14.8 & & $44^{\circ} 28^{\prime} 38^{\prime \prime} \mathrm{N} / 114^{\circ} 21^{\prime} 17^{\prime \prime} \mathrm{W}$ \\
\hline
\end{tabular}
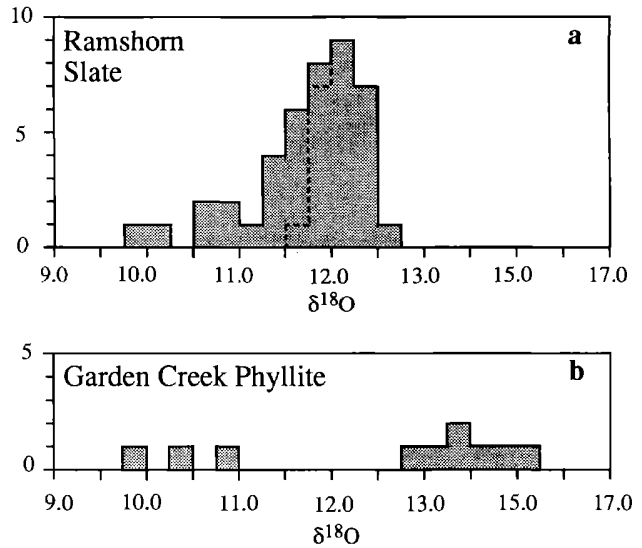

FIG. 3. Histogram of whole-rock $\delta^{18} \mathrm{O}$ values (\%o). (a). Ramshorn Slate. Dashed line approximates the lower limb of the inferred population of unaltered samples. (b). Garden Creek Phyllite. Unaltered values are assumed to be those above 14 per mil.

tion suggests that part of the Ramshorn Slate has been isotopically altered, presumably through exchange with isotopically light ancient meteoric waters, with altered samples represented by values below 11.5 per mil. On this basis, the maximum amount of isotopic alteration is approximately 2 per mil. Note that unaltered $\delta^{18} \mathrm{O}$ values between 11.5 and 12.6 per mil correspond to the lower limits of clastic rocks (Longstaffe, 1987). Also, three samples of the Ramshorn Slate yielded whole-rock $\delta \mathrm{D}$ values ranging from -84 to -71 per mil (Table 2). The larger variation in whole-rock $\delta \mathrm{D}$ values, compared to the $\delta^{18} \mathrm{O}$ values, is consistent with interactions under low water/rock conditions (Criss and Taylor, 1986).

The most depleted values from the slate are clustered adjacent to and north and south of the Nevada Mountain stock (Fig. 4). The spatial association of the altered $\delta^{18} \mathrm{O}$ values with the stock implies that the alteration and the intrusion were genetically related. The north-south elongation of the distribution of the anomalous values is thought to reflect the strongly developed secondary permeability, represented by the axial planar cleavage. The lack of altered $\delta^{18} \mathrm{O}$ values along the eastern contact with the Challis Volcanic Group suggests that the alteration event was unrelated to Eocene volcanism and thus preceded it.

Whole-rock $\delta^{18} \mathrm{O}$ values for Garden Creek Phyllite range from 10.0 to 15.1 per mil (Table 2) and thus span a wider range than those for the Ramshorn Slate (Fig. 3b). Criss and Fleck (1990) reported a similar range for hydrothermally altered metasedimentary rocks in northern Idaho. The data suggest that the Garden Creek Phyllite interacted more extensively with hydrothermal fluids than the stratigraphically higher Ramshorn Slate. The $\delta^{18} \mathrm{O}$ values from the Garden Creek Phyllite show no relationship with modal mineralogy (Seal, 1989) and suggest that the varia- 


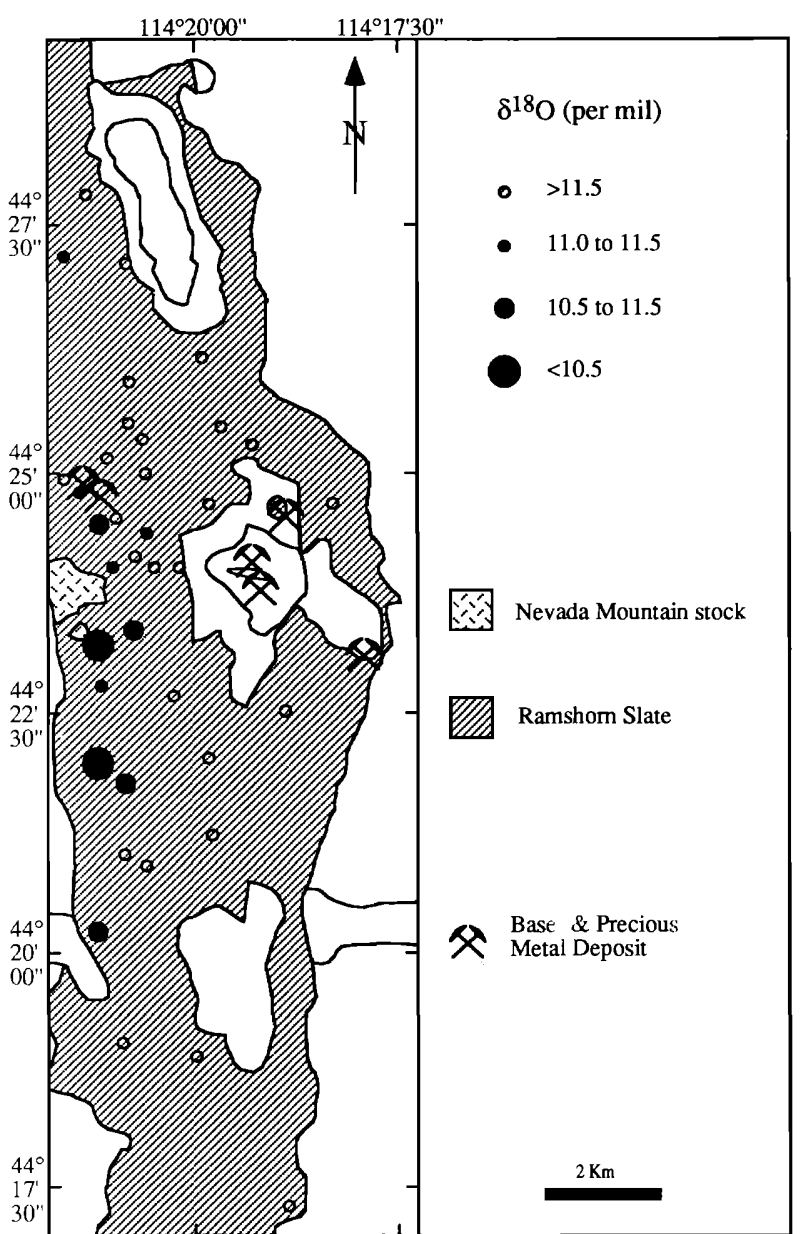

FIG. 4. Regional distribution of $\delta^{18} \mathrm{O}$ values (\%o) for the Ramshorn Slate. Note the north-south elongation of the zone of anomalous $(<11.5 \%)$ values. The outcrop pattern of the Ramshorn Slate and the Nevada Mountain stock are shown. See Figure 1 for detailed geology.

tion in isotopic values is due to alteration rather than mineralogical heterogeneities. The whole-rock $\delta \mathrm{D}$ values of the Garden Creek Phyllite range from -111 to -67 per mil, and when considered with the $\delta^{18} \mathrm{O}$ values, reflect low water/rock conditions (Table 2).

The regional distribution of the $\delta^{18} \mathrm{O}$ values for the Garden Creek Phyllite (Fig. 5) shows a zone of altered $\delta^{18} \mathrm{O}$ values around the Nevada Mountain stock. As with the Ramshorn Slate, the spatial association of the altered $\delta^{18} \mathrm{O}$ values with the stock implies that the alteration and the intrusion were contemporaneous and genetically related. The altered area in Figure 5 corresponds to approximately $60 \mathrm{~km}^{2}$. For a thickness of $230 \mathrm{~m}$ for the Garden Creek Phyllite (Hobbs, 1985a), this area represents a volume of 1.4 $\times 10^{16} \mathrm{~cm}^{3}$. Mabey and Webring (1985) reported a density of $2.67 \mathrm{~g} / \mathrm{cm}^{3}$ for the Paleozoic rocks of the district, which results in a mass of $3.7 \times 10^{16} \mathrm{~g}$ of altered rock. Mass balance considerations indicate that the amount of $\mathrm{Cu}, \mathrm{Pb}$, and $\mathrm{Fe}$ that was originally contained within this mass of rock was sufficient to account for all of the metal produced from the mines of the area (Seal, 1989). The mass of altered rock will also be important to evaluating potential sources of fluid salinity.

The two analyses of pyrite from the Garden Creek Phyllite (34.8 and 39.1\%o; Table 3) fall near the upper limits of values reported for sedimentary sulfates, consistent with the early Paleozoic age (Claypool et al., 1980). The $\delta^{13} \mathrm{C}$ values of carbonate-free organic matter from the Garden Creek Phyllite range from -23.6 to -20.9 per mil (Table 1).

\section{Geochemical Relationships of the Ore Deposits}

\section{Fluid inclusions}

Nature and occurrence: The quality of the fluid inclusion record associated with base and precious metal mineralization is highly variable, and in general, poor due to postdepositional deformation. However, rare specimens of quartz preserve a record of high-quality inclusions that yielded homogenization and freezing data.

Despite the lack of microthermometric data, the fluid inclusions hosted by stage I siderite warrant a brief description because of their relevance to the interpretation of stable isotope data. In general, the inclusions are scarce but can be categorized into two groups. The first group comprises small $(<15-\mu \mathrm{m}$ diam), equant inclusions that define growth zones,

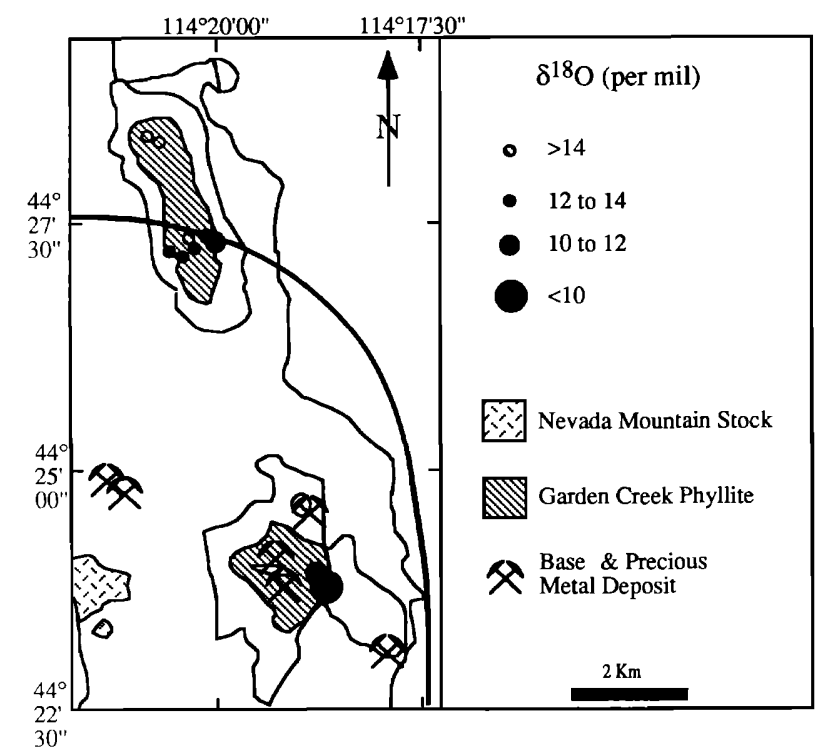

FIG. 5. Regional distribution of $\delta^{18} \mathrm{O}$ values (\%o) for the Garden Creek Phyllite. The outcrop pattern of the Garden Creek Phyllite and the Nevada Mountain stock are shown. The heavy line surrounds the inferred region of isotopic alteration of the Garden Creek Phyllite. See Figure 1 for detailed geology. 
TABLE 3. Sulfur Isotope Values (\%o)

\begin{tabular}{|c|c|c|c|c|}
\hline Sample no. & Mineral (stage) & $\delta^{34} \mathrm{~S}_{\mathrm{CDT}}$ & Latitude/longitude & Comments \\
\hline PACM-4-4 & Gn (II) & 8.9 & $44^{\circ} 24^{\prime} 35^{\prime \prime} \mathrm{N} / 114^{\circ} 18^{\prime} 59^{\prime \prime} \mathrm{W}$ & \\
\hline PACM-4-5 & Gn (II) & 11.5 & $44^{\circ} 24^{\prime} 35^{\prime \prime} \mathrm{N} / 114^{\circ} 18^{\prime} 59^{\prime \prime} \mathrm{W}$ & \\
\hline PACM-4-6 & Gn (II) & 9.2 & $44^{\circ} 24^{\prime} 35^{\prime \prime} \mathrm{N} / 114^{\circ} 18^{\prime} 59^{\prime \prime} \mathrm{W}$ & \\
\hline \multirow[t]{2}{*}{ PACM-4-7 } & Gn (II) & 9.9 & $44^{\circ} 24^{\prime} 35^{\prime \prime} \mathrm{N} / 114^{\circ} 18^{\prime} 59^{\prime \prime} \mathrm{W}$ & $\Delta_{\text {sphalerite-galena }}=2.7$ \\
\hline & Sp (II) & 12.6 & $44^{\circ} 24^{\prime} 35^{\prime \prime} \mathrm{N} / 114^{\circ} 18^{\prime} 59^{\prime \prime} \mathrm{W}$ & $\mathrm{T}=236^{\circ} \mathrm{C}$ \\
\hline \multirow[t]{2}{*}{ RIVM-D1 } & Gn (II) & 9.7 & $44^{\circ} 23^{\prime} 11^{\prime \prime} \mathrm{N} / 114^{\circ} 17^{\prime} 47^{\prime \prime} \mathrm{W}$ & $\Delta_{\text {sphalerite-galena }}=2.2$ \\
\hline & $\mathrm{Sp}(\mathrm{II})$ & 11.9 & $44^{\circ} 23^{\prime} 11^{\prime \prime} \mathrm{N} / 114^{\circ} 17^{\prime} 47^{\prime \prime} \mathrm{W}$ & $\mathrm{T}=291^{\circ} \mathrm{C}$ \\
\hline RIVM-D5 & $\mathrm{Gn}(\mathrm{II})$ & 9.1 & $44^{\circ} 23^{\prime} 11^{\prime \prime} \mathrm{N} / 114^{\circ} 17^{\prime} 47^{\prime \prime} \mathrm{W}$ & \\
\hline RIVM-D6 & Gn (II) & 8.8 & $44^{\circ} 23^{\prime} 11^{\prime \prime} \mathrm{N} / 114^{\circ} 17^{\prime} 47^{\prime \prime} \mathrm{W}$ & \\
\hline \multirow[t]{2}{*}{ RIVM-D8 } & Gn (II) & 7.8 & $44^{\circ} 23^{\prime} 11^{\prime \prime} \mathrm{N} / 114^{\circ} 17^{\prime} 47^{\prime \prime} \mathrm{W}$ & $\Delta_{\text {sphalerite-galena }}=2.3$ \\
\hline & $\mathrm{Sp}$ (II) & 10.1 & $44^{\circ} 23^{\prime} 11^{\prime \prime} \mathrm{N} / 114^{\circ} 17^{\prime} 47^{\prime \prime} \mathrm{W}$ & $\mathrm{T}=279^{\circ} \mathrm{C}$ \\
\hline CRAT-D8 & Gn (II) & 21.1 & $44^{\circ} 26^{\prime} 28^{\prime \prime} \mathrm{N} / 114^{\circ} 20^{\prime} 00^{\prime \prime} \mathrm{W}$ & \\
\hline BYHQ-174 & Py (GCP) & 39.1 & $44^{\circ} 28^{\prime} 41^{\prime \prime} \mathrm{N} / 114^{\circ} 21^{\prime} 23^{\prime \prime} \mathrm{W}$ & \\
\hline BYHQ-175 & Py (GCP) & 34.8 & $44^{\circ} 28^{\prime} 38^{\prime \prime} \mathrm{N} / 114^{\circ} 21^{\prime} 17^{\prime \prime} \mathrm{W}$ & \\
\hline BYHQ-211 & Py (BC) & 28.3 & $44^{\circ} 24^{\prime} 00^{\prime \prime} \mathrm{N} / 114^{\circ} 19^{\prime} 14^{\prime \prime} \mathrm{W}$ & From quartz vein \\
\hline BARM-D1 & Gn (II) & 3.0 & $44^{\circ} 23^{\prime} 51^{\prime \prime} \mathrm{N} / 114^{\circ} 19^{\prime} 07^{\prime \prime} \mathrm{W}$ & \\
\hline RAMM-DI & Gn (II) & 8.8 & $44^{\circ} 24^{\prime} 38^{\prime \prime} \mathrm{N} / 114^{\circ} 21^{\prime} 40^{\prime \prime} \mathrm{W}$ & \\
\hline RAMM-D4 & Py (post-II) & -8.2 & $44^{\circ} 24^{\prime} 38^{\prime \prime} \mathrm{N} / 114^{\circ} 21^{\prime} 40^{\prime \prime} \mathrm{W}$ & \\
\hline \multirow[t]{3}{*}{ RAMM-D12 } & Td $(\mathrm{I})$ & 8.8 & $44^{\circ} 24^{\prime} 38^{\prime \prime} \mathrm{N} / 114^{\circ} 21^{\prime} 40^{\prime \prime} \mathrm{W}$ & \\
\hline & $\operatorname{Cp}(\mathrm{I})$ & 10.3 & $44^{\circ} 24^{\prime} 38^{\prime \prime} \mathrm{N} / 114^{\circ} 21^{\prime} 40^{\prime \prime} \mathrm{W}$ & \\
\hline & Gn (II) & 11.0 & $44^{\circ} 24^{\prime} 38^{\prime \prime} \mathrm{N} / 114^{\circ} 21^{\prime} 40^{\prime \prime} \mathrm{W}$ & \\
\hline RAMM-DI4 & $\mathrm{Gn}(\mathrm{II})$ & 9.0 & $44^{\circ} 24^{\prime} 38^{\prime \prime} \mathrm{N} / 114^{\circ} 21^{\prime} 40^{\prime \prime} \mathrm{W}$ & \\
\hline \multirow[t]{2}{*}{ RAMM-D15 } & $\mathrm{Td}(\mathbf{I})$ & 11.5 & $44^{\circ} 24^{\prime} 38^{\prime \prime} \mathrm{N} / 114^{\circ} 21^{\prime} 40^{\prime \prime} \mathrm{W}$ & \\
\hline & Gn (II) & 10.4 & $44^{\circ} 24^{\prime} 38^{\prime \prime} \mathrm{N} / 114^{\circ} 21^{\prime} 40^{\prime \prime} \mathrm{W}$ & \\
\hline RAMM-D1 8 & $\operatorname{Td}(\mathrm{II})$ & 10.2 & $44^{\circ} 24^{\prime} 38^{\prime \prime} \mathrm{N} / 114^{\circ} 21^{\prime} 40^{\prime \prime} \mathrm{W}$ & \\
\hline RAMM-TD & Td $(\mathrm{I})$ & 4.7 & $44^{\circ} 24^{\prime} 38^{\prime \prime} \mathrm{N} / 114^{\circ} 21^{\prime} 40^{\prime \prime} \mathrm{W}$ & \\
\hline SGKM-D3 & $\mathrm{Cp}(\mathrm{I})$ & 9.2 & $44^{\circ} 24^{\prime} 04^{\prime \prime} \mathrm{N} / 114^{\circ} 19^{\prime} 18^{\prime \prime} \mathrm{W}$ & \\
\hline
\end{tabular}

Abbreviations: Deposits: BARM $=$ Barton mine, CRAT $=$ Crater Claims, PACM $=$ Pacific mine, RAMM = Ramshorn mine, RIVM = Riverview mine, SGKM = Silver Greek mine; stages: I = stage I, II = stage II; BC = quartz vein hosted by basal dolomite of Bayhorse Creek, GCP = metasedimentary pyrite from Garden Creek Phyllite; minerals: $\mathrm{Cp}=$ chalcopyrite, $\mathrm{Gn}=$ galena, $\mathrm{Py}=\mathrm{pyrite}, \mathrm{Sp}=\mathrm{sphaler}-$ ite, $\mathbf{T d}=$ tetrahedrite

and thus probably represent primary inclusions. The second group consists of smaller $(<10-\mu \mathrm{m}$ diam) inclusions that occur along healed fractures and cleavage planes, indicative of either a pseudosecondary or secondary origin. All inclusions appear to be two phase, liquid rich, and aqueous.

Fluid inclusions of sufficient quality to permit microthermometric measurements were found in stage II quartz in a limited number of samples from the Barton and Ramshorn vein deposits and from the $\mathrm{Pa}$ cific and Riverview carbonate-hosted deposits. A single quartz sample from the Barton mine (BARM-D5) contains abundant large $(<100-\mu \mathrm{m}$ diam) fluid inclusions. The inclusions form a randomly distributed, three-dimensional array of negative crystals that are apparently unrelated to healed fractures and thus are indicative of a primary origin (Roedder, 1979). The inclusions are three phase $\left(\mathrm{H}_{2} \mathrm{O}\right.$-liquid $+\mathrm{CO}_{2}$-liquid + vapor) and exhibit constant phase ratios throughout the specimen. The consistency of the phase ratios implies that the inclusions were trapped from a single-phase fluid. Volume estimates for phases in individual inclusions indicate that the hydrothermal fluids contained $8.3 \pm 1.4$ mole percent $\mathrm{CO}_{2}$, which compares favorably with a manometrically determined value of 8.4 mole percent from a fluid inclusion extract.
Fluid inclusions in quartz from the carbonatehosted deposits can be grouped into two textural categories that are similar to the Barton inclusions. The first and rarest category consists of large $(50-75-\mu \mathrm{m}$ diam) anhedral inclusions, whose isolated occurrence and lack of relationship to healed fractures suggest a primary origin. The inclusions contain three phases at room temperature $\left(\mathrm{H}_{2} \mathrm{O}\right.$-liquid $+\mathrm{CO}_{2}$-liquid + vapor). The second group consists of large $(10-75-\mu \mathrm{m}$ diam) inclusions that fill healed fractures of unknown extent and imply either a pseudosecondary or secondary origin. The fracture-controlled inclusions comprise two-phase aqueous $\left(\mathrm{H}_{2} \mathrm{O}\right.$-liquid + vapor $)$, twophase carbonic $\left(\mathrm{CO}_{2}\right.$-liquid + vapor $)$, and threephase $\left(\mathrm{H}_{2} \mathrm{O}\right.$-liquid $+\mathrm{CO}_{2}$-liquid + vapor $)$ inclusions having variable phase ratios. The presence of texturally similar $\mathrm{H}_{2} \mathrm{O}$-rich and $\mathrm{CO}_{2}$-rich three-phase inclusions apparently records fluid immiscibility $\left(\mathrm{CO}_{2}\right.$ effervescence), in sharp contrast to the homogeneous fluid responsible for the Barton quartz.

The Ramshorn fluid inclusions differ significantly from the Barton, Pacific, and Riverview inclusions. The Ramshorn inclusions are hosted by quartz which postdated siderite and tetrahedrite and are accompanied by galena deposition (stage II). The inclusions form two populations. Inclusions from both are small $(<25-\mu \mathrm{m}$ diam), equant, anhedral, two phase, liquid 
rich, and aqueous. The first group occurs as isolated, single inclusions, that are apparently unrelated to healed fractures, and thus probably represent primary inclusions. The second set fills healed fractures, which implies either pseudosecondary or secondary origins.

Microthermometry: The fluid inclusion data from the vein and carbonate-hosted deposits were presented by Seal (1989). For $\mathrm{CO}_{2}$-bearing inclusions from both vein and carbonate-hosted deposits, $\mathrm{CO}_{2}$ triple-point and $\mathrm{CO}_{2}$ homogenization temperatures range from $-57.3^{\circ}$ to $-56.7^{\circ} \mathrm{C}$ and from $13.1^{\circ}$ to $30.6^{\circ} \mathrm{C}$, respectively. These data indicate that the methane $\left(\mathrm{CH}_{4}\right)$ content of the $\mathrm{CO}_{2}$-bearing phase is less than 5 mole percent (Burruss, 1981).

For the vein deposit, salinities range from 15.0 to 20.0 wt percent $\mathrm{NaCl}$ equiv, whereas for the carbonate-hosted deposits, they range from 2 to $15 \mathrm{wt}$ percent $\mathrm{NaCl}$ equiv. These estimates are based on the final melting temperatures $\left(\mathrm{T}_{\mathrm{m}}\right)$ of $\mathrm{CO}_{2}$ clathrate for three-phase inclusions (Collins, 1979) and of ice for two-phase, aqueous inclusions (Potter et al., 1978).

Only three homogenization temperatures were obtained $\left(180^{\circ}, 187^{\circ}\right.$, and $\left.226^{\circ} \mathrm{C}\right)$ from the Ramshorn quartz sample fluid inclusions because of the scarcity, small size, mottled surface, and common decrepitation. In addition, the three-phase fluid inclusions from the Barton, Pacific, and Riverview deposits typically decrepitated between $217^{\circ}$ and $315^{\circ} \mathrm{C}$ prior to homogenization. However, two apparent primary inclusions in quartz from the Barton mine were successfully homogenized at $280^{\circ}$ and $301^{\circ} \mathrm{C}$. For the carbonate-hosted deposits, homogenization temperatures $\left(T_{h}\right)$ for three-phase (primary and fracture-controlled) fluid inclusions range from $206^{\circ}$ to $282^{\circ} \mathrm{C}$; temperatures for two-phase aqueous (fracture-controlled) inclusions range from $99^{\circ}$ to $206^{\circ} \mathrm{C}$.

Pressure and depth estimates and entrapment temperatures: The constant $\mathrm{CO}_{2} / \mathrm{H}_{2} \mathrm{O}$ ratios in fluid inclusions from the Barton mine and the variable ratios found in the Pacific and Riverview mines suggest that the mineralizing fluids evolved from a homogeneous to an effervescing (immiscible) state during stage II. For a given temperature and fluid composition, this transition defines a unique pressure. On the basis of the data presented above, the single-phase fluid is interpreted to contain 8.3 mole percent $\mathrm{CO}_{2}$ and 20 wt percent $\mathrm{NaCl}$. The phase relations for a fluid of this composition, derived from the data of Takenouchi and Kennedy (1965), are presented in Figure 6. Homogenization temperatures between $280^{\circ}$ and $301^{\circ} \mathrm{C}$ from the Barton mine inclusions thus place a minimum limit on the confining pressure of approximately 1.1 kbars (Fig. 6). Conversely, sulfur isotope and fluid inclusion homogenization data indicate a peak temperature of $235^{\circ}$ to $290^{\circ} \mathrm{C}$ associated with sulfide deposition and effervescence in the Pacific

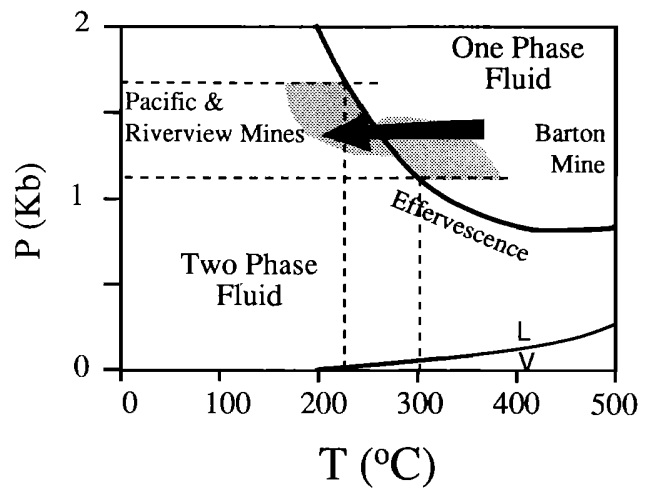

FIG. 6. Phase relations in the system $\mathrm{H}_{2} \mathrm{O}-\mathrm{CO}_{2}-\mathrm{NaCl}$ as applied to the Bayhorse district. The diagram is constructed for $\mathrm{X}_{\mathrm{CO}_{2}}$ $=0.083$ from the data of Takenouchi and Kennedy (1952). The fields for the Pacific and Riverview mines and the Barton mine only represent maximum and minimum pressure limits, respectively. The large arrow represents the cooling inferred for the Bayhorse hydrothermal system from stage I to stage II. See text for description of temperature and pressure limits.

and Riverview mines. $\mathrm{CO}_{2}$ effervescence in this temperature range places a maximum limit on pressure of approximately 1.7 kbars (Fig. 6). This pressure range corresponds to depths between 9 and $17 \mathrm{~km}$ for hydrostatic and between 3.5 and $6.5 \mathrm{~km}$ for lithostatic conditions.

For the $\mathrm{CO}_{2}$-bearing inclusions, the temperature corrections resulting from elevated pressures of entrapment should be minimal because the fluids were trapped at conditions on or near the solvus in the $\mathrm{H}_{2} \mathrm{O}-\mathrm{CO}_{2}-\mathrm{NaCl}$ system. The temperature corrections for fluid inclusions from the Barton mine would range from nil at $1.1 \mathrm{kbars}$ to $60^{\circ} \mathrm{C}$ at $1.7 \mathrm{kbars}$ (Bowers and Helgeson, 1983). Corrected entrapment temperatures for the two-phase inclusions from the Ramshorn mine range from $285^{\circ}$ to $331^{\circ} \mathrm{C}$ at $1.1 \mathrm{kbars}$ and from $330^{\circ}$ to $376^{\circ} \mathrm{C}$ at $1.7 \mathrm{kbars}$ (Potter, 1977), for a salinity of 15 wt percent $\mathrm{NaCl}$.

\section{Stable isotope relationships}

Quartz: Hydrothermal quartz associated with both carbonate-hosted $\mathrm{Pb}-\mathrm{Zn}$-Ag and vein $\mathrm{Cu}-\mathrm{Ag}$ mineralization shows a limited range of $\delta^{18} \mathrm{O}$ values from 14.1 to 16.3 per mil (Table 4). At a constant $\delta^{18} \mathrm{O}_{\mathrm{H}_{2} \mathrm{O}}$, this spread corresponds to a temperature difference of approximately $70^{\circ} \mathrm{C}$. The tight clustering of the $\delta^{18} \mathrm{O}$ values implies that the fluids that deposited the quartz throughout the district were isotopically homogeneous and suggests that quartz deposition did not result from fluid mixing.

Siderite: The hydrothermal siderites of the district also display a limited range of $\delta^{13} \mathrm{C}(-6.1$ to $-4.4 \%)$ and $\delta^{18} \mathrm{O}(13.6-15.8 \%$ ) values (Table 4$)$, which also suggests that fluid mixing was unimportant during their deposition. For a given $\delta^{18} \mathrm{O}$ value, the Silver 
TABLE 4. Oxygen, Carbon, and Hydrogen Isotope Values (\%o) for Hydrothermal Phases

\begin{tabular}{|c|c|c|c|c|c|c|c|c|c|}
\hline \multirow[b]{2}{*}{ Sample no. } & \multirow[b]{2}{*}{ Phase } & \multirow[b]{2}{*}{$\delta^{18} \mathrm{O}_{\text {phase }}$} & \multirow[b]{2}{*}{$\delta^{13} \mathrm{C}_{\text {phase }}$} & \multirow[b]{2}{*}{$\delta \mathrm{D}_{(f)}$} & \multirow[b]{2}{*}{$\delta^{18} \mathbf{O}_{(f)}$} & \multirow[b]{2}{*}{$\delta^{18} \mathrm{O}_{(\mathrm{clc}, f)}$} & \multirow[b]{2}{*}{$\delta^{13} \mathrm{C}_{(\mathrm{clc}, f)}$} & \multicolumn{2}{|c|}{ Inclusion yield } \\
\hline & & & & & & & & $\mathrm{H}_{2} \mathrm{O}(\mathrm{mg})$ & $\mathrm{CO}_{2}(\mathrm{mg})$ \\
\hline \multirow[t]{2}{*}{ BARMD5 } & $\mathrm{Qz}$ & 14.4 & & -112 & & 8.6 & & 8.9 & 2.0 \\
\hline & $\mathrm{CO}_{2}$ & 22.0 & -2.1 & & & & & & \\
\hline \multirow[t]{4}{*}{ RAMMD5 } & $\mathrm{Sd}$ & 14.4 & -6.1 & -115 & & 9.8 & -9.1 & & \\
\hline & $\mathrm{Sd}$ & & & -107 & -8.9 & & & 5.1 & \\
\hline & $\mathrm{Td}$ & & & -111 & -8.0 & & & 7.4 & 0.4 \\
\hline & $\mathrm{CO}_{2}$ & 41.2 & -2.1 & & & & & & \\
\hline RAMMD6 & Sd & 14.7 & -5.8 & & & 10.1 & -8.8 & & \\
\hline \multirow[t]{3}{*}{ RAMMD10 } & $\mathrm{Sd}$ & 14.1 & -5.8 & & 9.1 & 9.5 & -8.8 & 8.4 & \\
\hline & $\mathrm{Qz}$ & 14.2 & & -146 & & 8.4 & & 15.8 & 0.8 \\
\hline & $\mathrm{CO}_{2}$ & 20.2 & -4.0 & & & & & & \\
\hline RAMMD11L & $\mathrm{Sd}$ & 15.4 & -5.1 & & & 10.8 & -8.1 & & \\
\hline RAMMDI ID & $\mathrm{Sd}$ & 14.7 & -5.0 & & & 10.1 & -8.0 & & \\
\hline RAMMD12 & $S d$ & 14.3 & -5.9 & & & 9.7 & -8.9 & & \\
\hline \multirow[t]{2}{*}{ RAMMD13 } & Sd & 15.0 & -5.9 & -128 & & 10.4 & -8.9 & & \\
\hline & Sd & & & -135 & -15.2 & & & 5.2 & \\
\hline \multirow[t]{2}{*}{ RAMMD14 } & $\mathrm{Sd}$ & 15.8 & -4.8 & -119 & & 11.2 & -7.8 & 12.8 & \\
\hline & $\mathrm{Qz}$ & 15.6 & & -130 & & 9.8 & & 12.0 & \\
\hline \multirow[t]{3}{*}{ RAMMD15 } & Sd & 14.6 & -5.5 & -134 & & 10.0 & -8.5 & & \\
\hline & Sd & & & -125 & -11.9 & & & 6.2 & \\
\hline & $\mathrm{Td}$ & & & -121 & -8.2 & & & 12.3 & \\
\hline \multirow[t]{2}{*}{ RAMMD18 } & Sd & 15.1 & -5.3 & & & 10.5 & -8.3 & & \\
\hline & $\mathrm{Td}$ & & & -118 & -5.3 & & & 15.4 & 0.2 \\
\hline RAMMD20 & Sd & 14.7 & -5.0 & & & 10.1 & -8.0 & & \\
\hline RAMMTD & $\mathrm{Td}$ & & & -107 & 6.1 & & & 19.5 & 0.1 \\
\hline SGKMD3 & Sd & 13.6 & -4.4 & & 8.6 & 9.0 & -7.4 & & \\
\hline SGKMD6 & Sd & 13.7 & -4.7 & & 8.7 & 9.1 & -7.7 & & \\
\hline SKYMD6 & $\mathrm{Sd}$ & 14.7 & -5.9 & & 9.7 & 10.1 & -8.9 & & \\
\hline \multirow[t]{2}{*}{ SKYM66 } & $\mathrm{Qz}$ & 15.0 & & -138 & 9.2 & & & 10.6 & 0.6 \\
\hline & $\mathrm{CO}_{2}$ & 22.8 & -3.4 & & & & & & \\
\hline UMNTDH9 & $\mathrm{Sd}$ & 13.7 & -5.7 & & & 9.1 & -8.7 & & \\
\hline PACM4-5 & $\mathrm{Qz}$ & 14.5 & & -144 & & 4.3 & & 3.3 & 0.1 \\
\hline \multirow[t]{2}{*}{ PACM4-7 } & $\mathrm{Qz}$ & 14.1 & & -143 & & 3.9 & & 15.5 & 2.4 \\
\hline & $\mathrm{CO}_{2}$ & 6.8 & -1.8 & & & & & & \\
\hline RIVMD6 & $\mathrm{Qz}$ & 16.3 & & -135 & & 8.3 & 3.5 & 1.9 & \\
\hline
\end{tabular}

All calculations at $350^{\circ} \mathrm{C}$ except samples PACM4-5 and PACM4-7 at $236^{\circ} \mathrm{C}$ and sample RIVMD6 at $285^{\circ} \mathrm{C} ; \delta^{18} \mathrm{O}$ and $\delta \mathrm{D}$ relative to SMOW, $\delta^{13} \mathrm{C}$ relative to $\mathrm{PDB}$

Abbreviations: BARM = Barton mine $\left(44^{\circ} 24^{\prime} 35^{\prime \prime} \mathrm{N} / 114^{\circ} 18^{\prime} 59^{\prime \prime} \mathrm{W}\right), \mathrm{PACM}=$ Pacific mine $\left(44^{\circ} 24^{\prime} 35^{\prime \prime} \mathrm{N} / 114^{\circ} 18^{\prime} 59^{\prime \prime} \mathrm{W}\right), \mathrm{RAMM}$ $=$ Ramshorn mine $\left(44^{\circ} 24^{\prime} 38^{\prime \prime} \mathrm{N} / 114^{\circ} 21^{\prime} 40^{\prime \prime} \mathrm{W}\right)$, RIVM = Riverview mine $\left(44^{\circ} 23^{\prime} 11^{\prime \prime} \mathrm{N} / 114^{\circ} 17^{\prime} 47^{\prime \prime} \mathrm{W}\right)$, SGKM = Silver Greek mine $\left(44^{\circ} 24^{\prime} 04^{\prime \prime} \mathrm{N} / 114^{\circ} 19^{\prime} 18^{\prime \prime} \mathrm{W}\right)$, SKYM = Skylark mine $\left(44^{\circ} 24^{\prime} 55^{\prime \prime} \mathrm{N} / 114^{\circ} 21^{\prime} 54^{\prime \prime} \mathrm{W}\right)$, UMNT = Umont drill core $\left(44^{\circ} 24^{\prime} 29^{\prime \prime} \mathrm{N} / 114^{\circ} 21^{\prime} 45^{\prime \prime}\right.$ W); $\mathrm{CO}_{2}=\mathrm{CO}_{2}$ liberated from quartz-hosted fluid inclusions; $\mathrm{Qz}=$ quartz, $\mathrm{Sd}=$ siderite, $\mathrm{Td}=$ tetrahedrite-hosted fluid inclusions; $\delta^{18} \mathrm{O}_{\text {phase }}, \delta^{13} \mathrm{C}_{\text {phase }}=$ mineral isotopic value, $\delta \mathrm{D}_{(f)}, \delta^{18} \mathrm{O}_{(f)}=$ isotopic value for fluid inclusion extract, $\delta^{18} \mathrm{O}_{(\mathrm{clc}, f)}, \delta^{13} \mathrm{C}_{(\mathrm{clc}, f)}=f l u i d$ isotopic value calculated from published mineral-fluid fractionation factors (see text)

Greek siderites have larger $\delta^{13} \mathrm{C}$ values than the Ramshorn-Skylark siderites. The UMNT-DH9 siderite, from drill core that sampled rocks structurally and stratigraphically below the Ramshorn vein system, yielded the lowest $\delta^{18} \mathrm{O}$ value $(13.7 \%$ ) from the district, which suggests that this siderite formed from the hottest fluids. The range of $\delta^{18} \mathrm{O}$ values is consistent with a temperature drop of approximately $70^{\circ} \mathrm{C}$ (Carothers et al., 1988), assuming a common fluid and an initial temperature of approximately $350^{\circ} \mathrm{C}$.

Sulfides: Hydrothermal sulfides and sulfosalts show a wide range of $\delta^{34} \mathrm{~S}$ values from -8.2 to 28.3 per mil but most cluster at $10.0 \pm 3.1$ per mil (Table 3$)$. In addition, Howe and Hall (1985) reported values for tetrahedrite, galena, and chalcopyrite from the
Ramshorn mine of $11.5,10.1$, and 11.3 per mil, respectively. The $\delta^{34} \mathrm{~S}$ values for galenas ranged from 3.0 to 21.1 per mil, and values for sphalerite ranged from 10.1 to 12.6 per mil (Table 3). Three sphaleritegalena pairs yielded $\Delta$ values ranging from 2.2 to 2.7 per mil, which are consistent with temperatures ranging from $236^{\circ}$ to $291^{\circ} \mathrm{C}$ (Czamanske and Rye, 1974).

Fluids: The data for stage I fluids were obtained from siderite and tetrahedrite. The $\delta^{18} \mathrm{O}_{\mathrm{H}_{2} \mathrm{O}}$ and $\delta \mathrm{D}_{\mathrm{H}_{2} \mathrm{O}}$ values were determined by two means. First, $\delta^{18} \mathrm{O}_{\mathrm{H}_{2} \mathrm{O}}$ values were calculated from the siderite $\delta^{18} \mathrm{O}$ values with siderite-water fractionation factors extrapolated from Carothers et al. (1988) assuming a temperature of $350^{\circ} \mathrm{C}$. The $\delta \mathrm{D}_{\mathrm{H}_{2} \mathrm{O}}$ values were mea- 
sured from inclusion fluids extracted from siderite. Second, $\delta^{18} \mathrm{O}_{\mathrm{H}_{2} \mathrm{O}}$ values and duplicate $\delta \mathrm{D}_{\mathrm{H}_{2} \mathrm{O}}$ values were determined from inclusion fluids extracted from both siderite and tetrahedrite (Table 4; Fig. 7). Manometrically determined $\mathrm{CO}_{2}$ contents for the inclusion extracts range from 2.2 to 0.3 mole percent (Table 4). The calculated siderite fluid values $\left(\delta^{18} \mathrm{O}_{\text {calculated, fluid }}\right)$ and the measured $\delta^{18} \mathrm{O}_{\text {fluid }}$ values from fluid inclusions differ significantly (Fig. 7). Moreover, $\delta^{18} \mathrm{O}_{\text {fluid }}$ values measured on extracts from coexisting tetrahedrite from the same sample show values similar to the siderite extracts and thus preclude postentrapment retrograde exchange at lower temperature as a cause of the discrepancy. Postentrapment isotopic reequilibration between inclusion fluid $\mathrm{CO}_{2}$ and $\mathrm{H}_{2} \mathrm{O}$ at low temperature $\left(\simeq 25^{\circ} \mathrm{C}\right)$ would lower the $\delta^{18} \mathrm{O}_{\mathrm{H}_{2} \mathrm{O}}$ values, but the magnitude of this effect is not sufficient to account for the discrepancy. For an inclusion containing 2.2 mole percent $\mathrm{CO}_{2}$, the shift would be less than 1.5 per mil; for an inclusion containing 0.3 mole percent $\mathrm{CO}_{2}$, the shift would be 0.1 per mil. The most likely explanation is that the measured values for siderite- and tetrahedrite-hosted fluids represent mixtures of the primary and secondary fluid inclusions observed in the samples. The low $\delta^{18} \mathrm{O}_{\mathrm{H}_{2} \mathrm{O}}$ values of these fluids indicate that the secondary fluid inclusions probably consisted largely of unexchanged meteoric waters. Foley et al. (1989) reached a similar conclusion for quartzhosted primary and pseudosecondary inclusion fluids from the Creede mining district, Colorado.

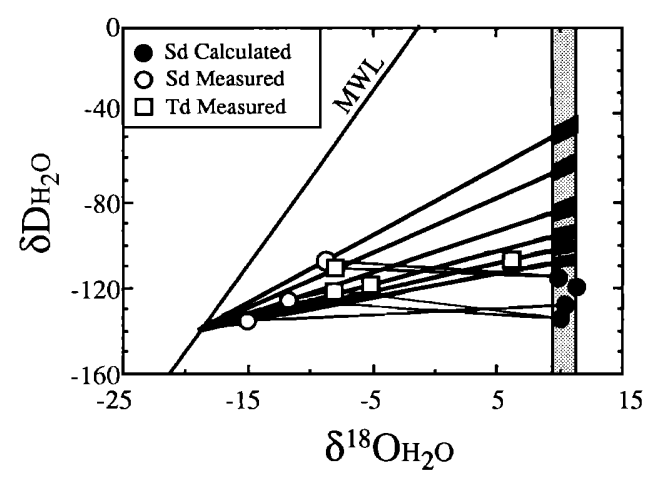

FIG. 7. The $\delta \mathrm{D}_{\mathrm{H}_{2} \mathrm{O}}$ and $\delta^{18} \mathrm{O}_{\mathrm{H}_{2} \mathrm{O}}$ variations of fluids associated with siderite $(\mathrm{Sd})$ and tetrahedrite (Td). The meteoric water line (MWL) is plotted for reference. Thin lines connect analyses from the same sample. The vertical gray zone represents the calculated $\delta^{18} \mathrm{O}_{\mathrm{H}_{2} \mathrm{O}}$ values for fluids in equilibrium with hydrothermal siderites. The heavy lines connect the inferred ancient meteoric water compositions with the mixed-population values extracted from siderites or cogenetic tetrahedrites and the calculated $\delta^{18} \mathrm{O}_{\mathrm{H}_{2} \mathrm{O}}$ values, represented by the vertical gray zone. The estimated primary $\delta \mathrm{D}_{\mathrm{H}_{2} \mathrm{O}}$ values (black parallelograms) are represented by the intersection of the heavy lines with the calculated $\delta^{18} \mathrm{O}_{\mathrm{H}_{2} \mathrm{O}}$ values. See text for additional discussion.
For stage II, the oxygen and hydrogen isotope data for fluids associated with hydrothermal quartz from the carbonate-hosted $\mathrm{Pb}-\mathrm{Zn}-\mathrm{Ag}$ deposits and from the $\mathrm{Cu}-\mathrm{Ag}$ veins display similar characteristics. The $\delta^{18} \mathrm{O}_{\mathrm{H}_{2} \mathrm{O}}$ values range from 3.9 to 9.8 per mil, and the $\delta \mathrm{D}_{\mathrm{H}_{2} \mathrm{O}}$ values range from -146 to -112 per mil. Samples BARM-D5, PACM-4-5, PACM-4-7, and RIVMD6 are dominated by primary and/or pseudosecondary fluid inclusions and therefore provide a reliable record of the ore-forming fluids that is not obscured by a large population of secondary inclusions. Therefore, the lowermost group of $\delta D_{\mathrm{H}_{2} \mathrm{O}}$ values probably represents a good estimate of the hydrogen isotope composition of the Cretaceous meteoric waters in the hydrothermal system $(\delta \mathrm{D} \simeq-140 \% 0)$. By analogy with modern meteoric waters (Craig, 1961), the $\delta^{18} \mathrm{O}$ value of the unexchanged meteoric water should have been -18.8 per mil. The Cretaceous meteoric water isotopic values are indistinguishable from estimates for the Eocene $\left(\delta^{18} \mathrm{O}=-19.1 \pm 1.4 \% 0, \delta \mathrm{D}\right.$ $=-138 \pm 5 \%)$ and modern $\left(\delta^{18} \mathrm{O}=-18.8 \pm 0.3 \%\right.$, $\delta \mathrm{D}=-140 \pm 1.0 \%$ ) values (Seal and Rye, 1991) .

Given the $\delta \mathrm{D}$ and $\delta^{18} \mathrm{O}$ values of one end member (meteoric water) and the value for the mixture, represented by the inclusion extracts, a line drawn through these points must intersect the calculated primary $\delta^{18} \mathrm{O}_{\mathrm{H}_{2} \mathrm{O}}$ value in equilibrium with the host siderite at $350^{\circ} \mathrm{C}$ at the $\delta \mathrm{D}_{\mathrm{H}_{2} \mathrm{O}}$ value of the primary fluid (Fig. 7). Although the origin of the secondary inclusions is uncertain, the equivalence of the isotopic values of Cretaceous, Eocene, and modern meteoric waters and Eocene hydrothermal fluids in the area (Seal and Rye, 1991) enables primary $\delta \mathrm{D}_{\mathrm{H}_{2} \mathrm{O}}$ to be extrapolated from the data measured on the inclusions extracts and calculated from the siderite mineral values. Thus, the primary fluids (Fig. 8) had a restricted $\delta^{18} \mathrm{O}_{\mathrm{H}_{2} \mathrm{O}}$ range $(10-12 \%)$ and a wide $\delta \mathrm{D}_{\mathrm{H}_{2} \mathrm{O}}$ range $(-110$ to $-55 \%)$. If the secondary inclusion fluid is a slightly exchanged Cretaceous meteoric water, then the extrapolated $\delta \mathrm{D}_{\mathrm{H}_{2} \mathrm{O}}$ will represent minimum values.

The $\delta^{13} \mathrm{C}_{\mathrm{CO}_{2}}$ values for the fluids associated with stage I hydrothermal activity were calculated from siderite $\delta^{13} \mathrm{C}$ values. At $350^{\circ} \mathrm{C}$, the siderite- $\mathrm{CO}_{2}$ carbon isotope fractionation factor is approximately 3.0 per mil, as extrapolated from the data of Carothers et al. (1988). Thus, the calculated $\delta^{13} \mathrm{C}_{\mathrm{CO}_{2}}$ values for stage I range from -9.1 to -7.4 per mil. The $\delta^{13} \mathrm{C}$ values associated with stage II hydrothermal activity were derived from fluid inclusion extracts from quartz, for which petrographic examination assured a high proportion of primary or pseudosecondary fluid inclusions. These $\delta^{13} \mathrm{C}_{\mathrm{CO}_{2}}$ values range from -4.0 to -1.8 per mil.

\section{Origin of Fluids and Ore Constituents}

The association with granitic rocks and metasedimentary country rocks, and the depth inferred for 


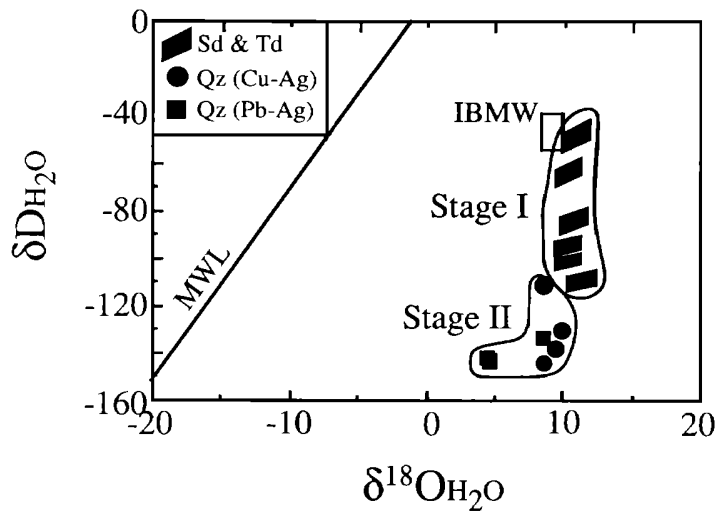

FIG. 8. The $\delta \mathrm{D}_{\mathrm{H}_{2} \mathrm{O}}$ and $\delta{ }^{18} \mathrm{O}_{\mathrm{H}_{2} \mathrm{O}}$ variations of primary ore fluids associated with base and precious metal mineralization. The siderite $(\mathrm{Sd})$ and tetrahedrite $(\mathrm{Td}) \delta \mathrm{D}_{\mathrm{H}_{2} \mathrm{O}}$ values are extrapolated from Figure 7. The siderite $\delta^{18} \mathrm{O}_{\mathrm{H}_{2} \mathrm{O}}$ values are calculated from the mineral $\delta^{18} \mathrm{O}$ values for a temperature of $350^{\circ} \mathrm{C}$; the tetrahedrite $\delta^{18} \mathrm{O}_{\mathrm{H}_{2} \mathrm{O}}$ values represent the bulk range calculated for cogenetic siderite. The field for Idaho batholith magmatic waters (IBMW) is plotted for reference (see text). MWL = meteoric water line, $\mathrm{Qz}$ $=$ quartz, $\mathrm{Sd}=$ siderite, $\mathrm{Td}=$ tetrahedrite.

mineralization, requires that magmatic, meteoric, and basinal brine sources of fluids be considered. The fluid inclusion and stable isotope characteristics of the stage II fluids may be used to exclude basinal brines, akin to those responsible for Mississippi Valley-type deposits, as a possible fluid sources. For a given salinity, the Stage II fluids are significantly hotter than corresponding basinal brines or Mississippi Valley-type fluids. Although the temperature and salinity characteristics of the Bayhorse ore-forming fluids are consistent with a basinal brine source, the stable isotope signatures are not. The most compelling evidence against a basinal brine origin for the ore fluids is that no modern basinal brines have been documented that show $\delta^{18} \mathrm{O}$ and $\delta \mathrm{D}$ values similar to the isotopic values for the Bayhorse fluids, particularly those with the lowest $\delta \mathrm{D}$ values. Therefore, typical basinal brines and Mississippi Valley-type fluids are not good analogues for the Bayhorse fluids, contrary to suggestions made by Hoagland (1979) on the basis of geologic considerations.

The assessment of the relative importance of magmatic and meteoric waters in the ore-forming fluids is more difficult solely on the basis of fluid inclusion and stable isotope data. The stage I and II ore fluids define a narrow range of $\delta^{18} \mathrm{O}_{\mathrm{H}_{2} \mathrm{O}}$, with a wide $(90 \%)$ range of $\delta \mathrm{D}_{\mathrm{H}_{2} \mathrm{O}}$ values. The lowest $\delta \mathrm{D}_{\mathrm{H}_{2} \mathrm{O}}$ values require a significant input of exchanged meteoric waters. However, the range of $\delta \mathrm{D}_{\mathrm{H}_{2} \mathrm{O}}$ values can be produced either by the interaction of isotopically light meteoric water with country rocks at intermediate to low water/rock ratios; or by the mixing of a primary magmatic fluid with highly exchanged meteoric water.
The presence of siderite and pyrite, among other sulfides, in both the vein deposits and the Garden Creek Phyllite indicates that the fluids in equilibrium with the ores and the phyllite would have had similar reduced oxidation states. The inferred reduced oxidation state is in sharp contrast to the higher oxidation state expected for magmatic fluids that would have been evolved from a granodiorite, such as the Nevada Mountain stock, which contains the assemblage quartz + magnetite + titanite (Wones, 1989). Thus, a magmatic origin for the ore-forming fluids would appear to be precluded by the minimal opportunity afforded a hypothetical magmatic fluid to equilibrate with the Garden Creek Phyllite due to the close proximity of the deposits, particularly the veins, to the Nevada Mountain stock; and by the apparent lack of petrographic evidence that oxidationreduction reactions occurred within the Garden Creek Phyllite in the vicinity of the ore deposits. Therefore, the inferred oxidation state of the ore fluids suggests that the hydrothermal system was dominated by meteoric fluids that equilibrated with the Garden Creek Phyllite prior to ore deposition.

Isotopically heavy ore mineral and metasedimentary $\delta^{34} S$ values indicate a significant country-rock sulfur component in the hydrothermal system. The inferred low redox state of the ore fluids with $\mathrm{H}_{2} \mathrm{~S}$ $\gg \mathrm{SO}_{2}$ precludes oxidation-reduction processes as a cause for the observed large $\delta^{34} \mathrm{~S}$ range. The distinct mode in the distribution of the $\delta^{34} \mathrm{~S}$ values can be attributed to the homogenizing effect of hydrothermal leaching of sulfur from a heterogeneous metasedimentary source within a confined aquifer. The isotopically heavy pyrite $(28.3 \%$ ) occurs with quartz and fills barren veinlets in the basal dolomite of Bayhorse Creek a few meters below the contact with the overlying Garden Creek Phyllite. The high $\delta^{34} S$ value suggests that the sulfur in the pyrite was remobilized from the overlying phyllite. The isotopically light pyrite $(-8.2 \%)$ fills small, late fractures which crosscut stage II quartz. The low $\delta^{34} \mathrm{~S}$ value of this pyrite may reflect late-stage oxidation of $\mathrm{H}_{2} \mathrm{~S}$ due to mixing with oxygenated waters during the waning stages of hydrothermal activity in the Bayhorse district.

Potential sources of carbon may be evaluated from the country-rock $\delta^{13} \mathrm{C}$ values which range from a low of approximately -23 per mil for the organic matter of the Garden Creek Phyllite to a high of 7 per mil for the Bayhorse Dolomite. Ohmoto and Rye (1979) and Ohmoto (1986) suggested that little fractionation is produced during oxidation or hydrolysis of organic carbon, or during dissolution of carbonate rocks. Thus, the close agreement between the $\delta^{13} \mathrm{C}$ values of the $\mathrm{CO}_{2}$ extracted from quartz-hosted stage II inclusion fluids and those of the basal dolomite of Bayhorse Creek suggests that this unit was an important source of stage II aqueous carbon. The low calculated 
$\delta^{13} \mathrm{C}$ values of the $\mathrm{CO}_{2}$ associated with the siderite (stage I) indicate a larger contribution of organic or deep-seated carbon. The higher $\delta^{13} \mathrm{C}$ values (for a given $\delta^{18} \mathrm{O}$ value) of the Silver Creek siderites probably represent a greater input of carbon derived from the basal dolomite of Bayhorse Creek and thus reflects the closer proximity of the deposit to this unit (Fig. 1).

The ores are dominated by the elemental suite $\mathrm{Fe}$, $\mathrm{Cu}$, and $\mathrm{Pb}$ with lesser but important $\mathrm{Ag}, \mathrm{Sb}$, and $\mathrm{Zn}$. Abundant iron was available for leaching by the ore fluids from siderite and pyrite in the Garden Creek Phyllite. The presence of minor amounts of chalcopyrite associated with (meta)sedimentary pyrite in the phyllite suggests that disseminated sulfide may have been the source of copper. The Garden Creek Phyllite also contains a significant amount of potassium feldspar which may have provided lead to the hydrothermal system.

\section{Isotopic Constraints on Water-Rock Interactions}

\section{Theoretical considerations}

The interpretation of the oxygen and hydrogen isotope data is based largely on the extensive efforts which have been made by numerous workers to understand stable isotope variations associated with water-rock interactions surrounding shallow-level intrusions (Sheppard et al., 1969; Ohmoto and Rye, 1974; Campbell et al., 1984; Criss and Taylor, 1986). Water/rock (W/R) ratios calculated using a closedsystem model provide a minimum estimate of the actual $\mathrm{W} / \mathrm{R}$ ratios associated with hydrothermal activity because they neglect isotopic alteration effects integrated throughout the duration of hydrothermal activity (Ohmoto, 1986). In the present study, a closedsystem model, where water is neither removed nor added to the system, will be used as a limiting case (Criss and Taylor, 1986).

Calculations were done assuming a temperature of $350^{\circ} \mathrm{C}$ for interactions that were restricted to the Garden Creek Phyllite. Whole-rock XRF data (Seal, 1989) indicate that the unaltered Garden Creek Phyllite contains approximately 50.6 wt percent oxygen. Quantitative X-ray diffraction studies demonstrate that muscovite is the dominant hydrogen-bearing phase in the rock and constitutes $37 \mathrm{wt}$ percent of the phyllite. A whole-rock oxygen isotope rock-water fractionation factor $(4.6 \%)$ was used that combined published quartz-water (Clayton et al., 1972) and muscovite-water (O’Neil and Taylor, 1969) fractionation factors that were normalized to the amount of oxygen in quartz and muscovite in the unaltered Garden Creek Phyllite. A $350^{\circ} \mathrm{C}$ muscovite-water hydrogen isotope fractionation factor of -38 per mil (Suzuoki and Epstein, 1976) was used in the calculations. The initial $\delta^{18} \mathrm{O}$ and $\delta \mathrm{D}$ were assumed to be
-18.8 and -140 per mil for the fluid and 14.3 and -67 per mil for the phyllite, respectively (Seal, 1989). These calculations result in reaction curves shown in Figure 9 for $\delta^{18} \mathrm{O}$ and $\delta \mathrm{D}$ variations in water and rock at specific $W / R$ ratios.

\section{Rock alteration}

The coupled $\delta^{18} \mathrm{O}$ and $\delta \mathrm{D}$ variations preserved by whole-rock samples of the Garden Creek Phyllite indicate that the rocks underwent depletion of both $\delta \mathrm{D}$ and $\delta^{18} \mathrm{O}$ values (Fig. 9). Comparison of these values with the hypothetical Garden Creek Phyllite alteration curve indicates that the isotopic variations are reasonably described by the model calculations. The position of the Garden Creek Phyllite values in terms of $\delta \mathrm{D}$ and $\delta^{18} \mathrm{O}$ space on the near-vertical limb of the water-rock curve indicates that these rocks record low $\mathbf{W} / \mathbf{R}$ conditions ( $\mathbf{W} / \mathrm{R}<0.1$; Fig. 9). Thus, the erratic spatial distribution of whole-rock $\delta^{18} \mathrm{O}$ values for the Garden Creek Phyllite (Fig. 5) probably reflects variable permeabilities.

\section{Water evolution}

The primary Bayhorse district ore fluids display the $\delta \mathrm{D}_{\mathrm{H}_{2} \mathrm{O}}$ and $\delta^{18} \mathrm{O}_{\mathrm{H}_{2} \mathrm{O}}$ characteristics that would be consistent with a low $\mathrm{W} / \mathrm{R}$ system, in agreement with the low $W / R$ conditions recorded by the Garden Creek Phyllite (Fig. 9). In detail, however, the closed-system exchange curve, based solely on interactions with the Garden Creek Phyllite, only provides a lower $\delta^{18} \mathrm{O}$ limit for the observed ore fluids (Fig. 10). Therefore, some factor in addition to interaction with the phyllite must have contributed to the enrichment of the fluids in ${ }^{18} \mathrm{O}$.

The Ramshorn Slate is isotopically lighter than the Garden Creek Phyllite and thus would not provide a

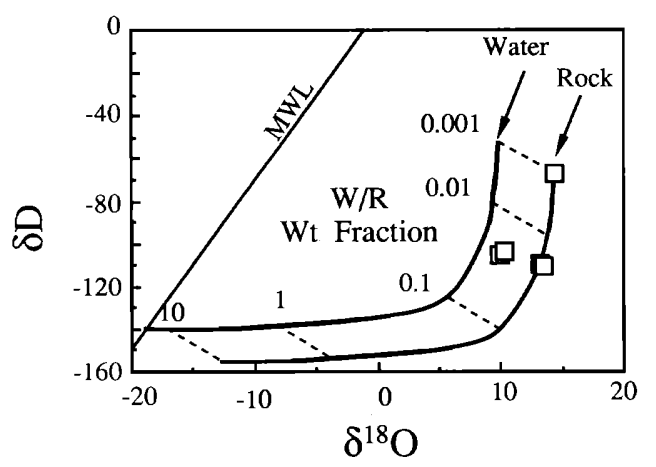

F1G. 9. Calculated exchange curves for water and rock compositions associated with ancient meteoric water-rock (Garden Creek Phyllite) interactions. The calculations were done for $350^{\circ} \mathrm{C}$. Corresponding water and rock values at various $\mathrm{W} / \mathrm{R}$ ratios are indicated by the dashed lines. Whole-rock data from the Garden Creek Phyllite are plotted as open squares. See text for additional discussion. 


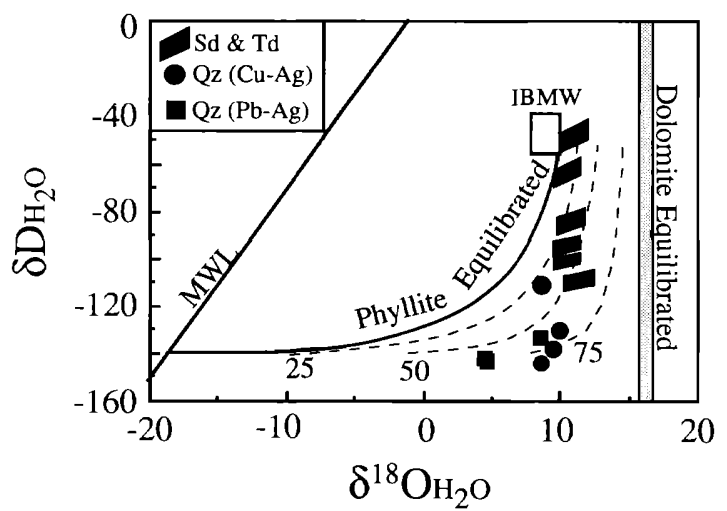

FIG. 10. Comparison of observed Bayhorse ore fluid data with the calculated exchange curve. The values of fluids in isotopic equilibrium with the basal dolomite of Bayhorse Creek at $350^{\circ} \mathrm{C}$ are indicated by the vertical gray zone. Mixtures of phyllite- and dolomite-equilibrated interactions are represented by the dashed curves labeled " 25 ," " 50 ," and " 75 " (\% dolomite-equilibrated water). The meteoric water line (MWL) and Idaho batholith magmatic waters (IBMW) are plotted for reference. $Q z=$ quartz, Sd $=$ siderite, $\mathrm{Td}=$ tetrahedrite.

feasible reservoir of heavy oxygen. In contrast, the Bayhorse Dolomite represents an isotopically heavier reservoir. The isotopic and geologic characteristics of the Bayhorse Dolomite suggest, however, that this unit acted as an impermeable layer. The basal dolomite of Bayhorse Creek, which underlies the Garden Creek Phyllite, represents a similar high $\delta^{18} \mathrm{O}$ reservoir. The water in isotopic equilibrium with the basal dolomite of Bayhorse Creek at $350^{\circ} \mathrm{C}$ can be calculated using the experimental dolomite-water oxygen isotope fractionation factors of Northrop and Clayton (1966). The potential range of $\delta^{18} \mathrm{O}_{\mathrm{H}_{2} \mathrm{O}}$ values for the fluid is shown in Figure 10, where mixtures of the "dolomite-equilibrated" fluid and the hypothetical "Garden Creek Phyllite" fluid are denoted by the $0.25,0.50$, and 0.75 isopleths, corresponding to weight fractions of "dolomite-equilibrated" water. Note that the isopleths only refer to mixing in terms of $\delta^{18} \mathrm{O}$ values because the dolomite does not contain any hydrogen to exchange with the reacting fluid. Thus, the isotopic signatures of the ore fluids are best explained by varying amounts of interaction with the Garden Creek Phyllite and the basal dolomite of Bayhorse Creek. The trend from the early tetrahedrite-siderite fluids (stage I) to the late quartz-galena fluids (stage II) transects the isopleths of "dolomite-equilibrated" fluid weight fractions and suggests that the later fluids interacted more extensively with the dolomite. The carbon isotope data from hydrothermal siderites and $\mathrm{CO}_{2}$ extracted from fluid inclusions also indicate that stage I fluids interacted more extensively with the Garden Creek Phyllite, whereas stage II fluids interacted more extensively with the basal dolomite of Bayhorse Creek.
$W / R$ ratios (in mass units) calculated from the $\delta^{18} \mathrm{O}_{\mathrm{H}_{2} \mathrm{O}}$ and unaltered Garden Creek Phyllite $\delta^{18} \mathrm{O}$ values range from 0.002 to 0.02 for stage $I$ fluids and from 0.03 to 0.09 for stage II. For a truly closed natural system, the $W / R$ ratio is equivalent to the porosity under water-saturated conditions. Ohmoto (1986) concluded that for natural closed systems, the $\mathbf{W} / \mathbf{R}$ values cannot exceed 0.02 to 0.1 because of the constraint placed by the porosity of the rock. Thus, for the stage II fluids of the Bayhorse district, minor amounts of open-system behavior may be implied. The detectable shift in the whole-rock $\delta^{18} \mathrm{O}$ values for the Garden Creek Phyllite (Fig. 9) also supports this conclusion (Ohmoto, 1986).

\section{Water-rock interactions and the origin of salinity}

The origin of the fluid salinity is important because of the significance of $\mathrm{Cl}$ complexes to metal transport. The temperature and salinity characteristics of the fluid inclusions are not definitive with regard to the origin of the fluid salinity. Compared to endmember magmatic fluids, the Bayhorse fluid inclusions fall at the low-salinity limit defined by inclusions from magmatic hydrothermal deposits such as Providencia (Rye, 1966) and Naica (Erwood et al., 1979), Mexico. The 5 to 20 wt percent salinities of the primary Bayhorse ore fluids are higher than most geothermal fluids where meteoric water is the dominant source of fluids. In modern geothermal fields, salinities of this magnitude are typically attributed to the dissolution of evaporites (White, 1980). Inasmuch as the metasedimentary rocks of the Bayhorse district have not been identified outside of the study area (Hobbs, 1985a), the failure to recognize evaporites in the limited exposure in the district may not necessarily preclude their potential as a source of chlorine.

The derivation of the salinity through leaching chlorine and sodium from the phyllite is an alternative possibility. Several average shale chlorine values are available from the literature that allow the Garden Creek Phyllite to be assessed a potential source of $\mathrm{NaCl}$. Wedepohl (1971) reported average contents of $180 \mathrm{ppm}$ for insoluble $\mathrm{Cl}$ and approximately $6,000 \mathrm{ppm}$ soluble Cl. Billings and Williams (1967) reported an average total $\mathrm{Cl}$ (insoluble and soluble) of $1,466 \mathrm{ppm}$. The $\mathrm{W} / \mathrm{R}$ ratios for the district $(0.002-$ 0.09 ) can be used to calculate potential salinities that can be produced with this range of $\mathrm{Cl}$ values assuming complete leaching of $\mathrm{Cl}$ from a constant mass of rock at various masses of water (Fig. 11). These ranges of $\mathrm{Cl}$ contents and $\mathrm{W} / \mathrm{R}$ ratios correspond to potential salinities ranging from 1.0 to $83.2 \mathrm{wt}$ percent $\mathrm{NaCl}$ (Fig. 11). However, the solubility of $\mathrm{NaCl}$ in water at $350^{\circ} \mathrm{C}$ places an upper limit of approximately 40 wt percent (Keevil, 1942). Sufficient sodium was available in the phyllite to balance this chlo- 


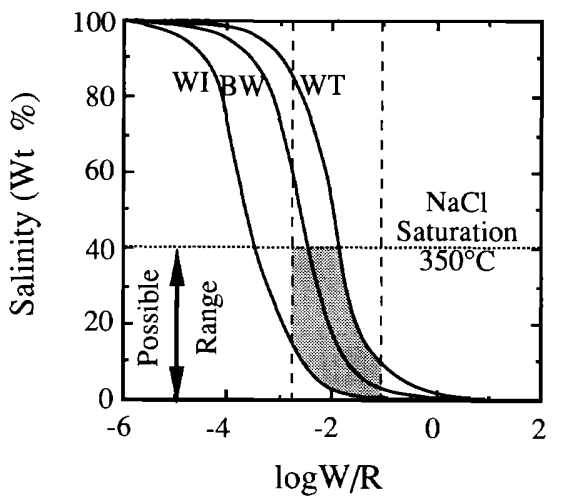

FIG. 11. The relationship between the $\mathrm{W} / \mathrm{R}$ ratio and potential salinity. The curves represent different published chlorine values for shales: WI $=$ Wedepohl $(1971)$, insoluble; $B W=$ Billings and Williams (1967); and WT = Wedepohl (1971), total Cl (insoluble and soluble). The shaded area represents the possible salinities for the Bayhorse hydrothermal system and is bound by the maximum and minimum calculated $W / R$ ratios, by the maximum and minimum shale chlorine curves calculated from literature values, and by the saturation of $\mathrm{NaCl}$ at $350^{\circ} \mathrm{C} . \mathrm{W} / \mathrm{R}=0.09, \log \mathrm{W} / \mathrm{R}=-1.1$; $\mathbf{W} / \mathbf{R}=0.002, \log \mathbf{W} / \mathbf{R}=-2.7$.

rine loss (Seal, 1989). Therefore, leaching of sodium and chlorine from the Garden Creek Phyllite alone can account for the observed fluid inclusion salinities.

\section{Relationship of Water-Rock Interactions to Paragenesis}

The isotopic characteristics of the ore fluids, ore constituents, and country rocks may be interpreted to have developed through the interaction of deeply circulating meteoric waters with the Garden Creek Phyllite and Bayhorse Dolomite, with all of the $\mathrm{Cl}$ for metal complexing and all of the ore constituents coming from these units. Consequently, magmatic contributions, other than heat to drive hydrothermal circulation, are not essential to explain the hydrothermal system. However, magmatic inputs other than heat cannot be completely ruled out. The ores themselves represent the combined products of processes that occurred both at the site of deposition and in the source region of the ore fluids and constituents. A temporal framework for processes at the site of deposition can be obtained from the paragenetic relationships among the ore and gangue minerals, but the source rocks only record cumulative information from throughout the lifetime of hydrothermal activity.

Both depositional and source region processes are ultimately governed by the ore-bearing capacity of the fluids, which is dependent upon the fluid salinity and $\mathrm{pH}$. The lack of evidence for fluid mixing at the site of deposition from stable isotope data indicates that the salinity and $\mathrm{CO}_{2}$ content differences between stages I and II must be a characteristic of the fluids prior to entering the site of deposition. A possible explanation of the temporal variation in salinity is that the earlier fluids which evolved at lower $\mathbf{W} / \mathbf{R}$ conditions (stage I) may have scavenged most of the $\mathrm{Cl}$ from the phyllite so that later fluids that evolved at slightly higher W/R conditions (stage II) may have had less chlorine available for leaching. The increased $\mathrm{CO}_{2}$ content of stage II fluids presumably reflects greater input from dissolution of the basal dolomite of Bayhorse Creek.

The $\mathrm{pH}$ of the ore fluids can be estimated by assuming that they equilibrated with the Garden Creek Phyllite, which contains the assemblage quartz + muscovite $+\mathrm{K}$ feldspar, with the reaction (Montoya and Hemley, 1975): $\mathrm{KAl}_{3} \mathrm{Si}_{3} \mathrm{O}_{10}(\mathrm{OH})_{2}+$ $6 \mathrm{SiO}_{2}+2 \mathrm{~K}^{+}=3 \mathrm{KAlSi}_{3} \mathrm{O}_{8}+2 \mathrm{H}^{+}$. Fluid inclusion data indicate that salinities reached a maximum of 20 wt percent $\mathrm{NaCl}$ equiv, which corresponds to an $\mathrm{Na}$ / $\mathrm{K}$ ratio of 3.0 using the $\mathrm{Na} / \mathrm{K}$ thermometer Fournier equation (Truesdell, 1984) at $350^{\circ} \mathrm{C}$. Using this potassium concentration, a $\mathrm{pH}$ of 5.1 is calculated for the early (stage I) fluid at $350^{\circ} \mathrm{C}$.

Depositional processes of potential importance in explaining the paragenetic sequence include decreasing temperature, $\mathrm{CO}_{2}$ effervescence, and for the carbonate-hosted deposits, acid neutralization through wall-rock dissolution. The fluid inclusion and stable isotope data from the ore deposits document a temperature decrease from $375^{\circ}$ to $225^{\circ} \mathrm{C}$. For sulfides and quartz, cooling would have promoted mineral precipitation. An additional important consequence of cooling was $\mathrm{CO}_{2}$ effervescence. The end of siderite deposition may reflect the onset of $\mathrm{CO}_{2}$ effervescence which abruptly decreased the fluid $f_{\mathrm{CO}_{2}}$ and drove solubility reactions, such as the following, to the right: $\mathrm{FeCO}_{3}+2 \mathrm{HCl}=\mathrm{FeCl}_{2}$ $+\mathrm{H}_{2} \mathrm{O}+\mathrm{CO}_{2}$. At lower temperatures, such as those inferred for the latter part of stage II, fluid immiscibility may have played a greater role in increasing $\mathrm{pH}$, and thus promoted sulfide deposition, due to the greater abundance of $\mathrm{HCO}_{3}^{-}$in the fluid. Even though the onset of $\mathrm{CO}_{2}$ effervescence can account for the end of siderite deposition, it cannot explain the paragenetic transition from early $\mathrm{Cu}$ to later $\mathrm{Pb}$.

The mineralogical differences between the hosts of $\mathrm{Cu}$ and $\mathrm{Pb}$ in the source rocks may, in part, be responsible for the transition from early $\mathrm{Cu}$ as tetrahedrite to late $\mathrm{Pb}$ as galena. The solubility of copper from sulfides such as metasedimentary chalcopyrite in the phyllite is a simple function of temperature and salinity. The hottest and most saline fluids (stage I) would have been capable of carrying the most copper. In contrast, metals that dominantly reside in silicate min- 
erals in the phyllite, such as $\mathrm{Pb}$ in $\mathrm{K}$ feldspar, owe their solubility to the stability of the silicate host. Hot, near-neutral deep meteoric waters would have been initially at conditions within the stability field of K feldspar, but not of muscovite. Thus, K feldspar would have sequestered its $\mathrm{Pb}$ from the hydrothermal fluids while chalcopyrite would have been actively dissolving. Later (higher $\mathbf{W} / \mathbf{R}$ conditions), cooler fluids interacting with the phyllite would have consumed $\mathrm{K}$ feldspar releasing its $\mathrm{Pb}$ to the fluid as the system progressed down temperature along the $\mathrm{K}$ feldspar + muscovite + quartz buffer (Fig. 12). By the time that significant amounts of $\mathrm{Pb}$ had been liberated to the ore fluids, the $\mathrm{Cu}$ supply may have been exhausted in the source rocks.

In summary, the transition from early siderite to late quartz deposition may have been the result of $\mathrm{CO}_{2}$ effervescence due to cooling at the site of deposition. In contrast, the transition from early high salinities to later lower salinities of the ore fluids and the transition from an early $\mathrm{Cu}$-rich character to a later $\mathrm{Pb}$-rich character appear to be the result of the evo-

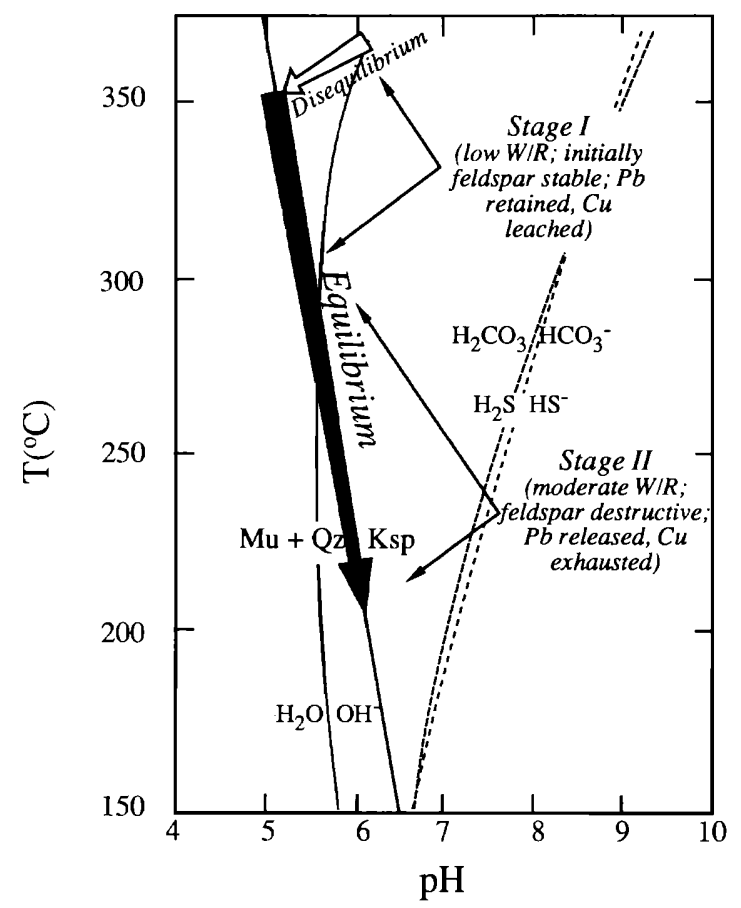

FIG. 12. The rock perspective of meteoric water/rock interactions in the Garden Creek Phyllite as a function of temperature and pH. Early (low W/R) near-neutral deeply circulating meteoric waters would have initially been out of equilibrium with the Garden Creek Phyllite. Equilibration with the phyllite would have buffered the fluids along the muscovite $(\mathrm{Mu})+$ quartz $(\mathrm{Qz})+\mathrm{K}$ feldspar (Ksp) curve for a fixed $\mathrm{K}^{+}$concentration. Later (higher $\mathrm{W} / \mathrm{R})$, cooler fluids would move down along the curve, consuming increasing amounts of $\mathrm{K}$ feldspar in the process. See text for additional discussion. Adapted from Barnes (1979). lution of water-rock interactions in the surrounding Garden Creek Phyllite. For the salinity, early low $\mathbf{W} / \mathbf{R}$ conditions may have scavenged much of the chlorine from the phyllite, thereby depleting the reservoir for later, slightly higher $\mathbf{W} / \mathbf{R}$ conditions. The paragenetic relationship of the ore metals appears to be related to differences in the stability of their mineral hosts in the Garden Creek Phyllite during hydrothermal leaching. Thus, the salinity variations of the fluids would have had a direct genetic link to water/ rock ratios in the system, whereas the ore metal and gangue mineral variations would have been the result of decreasing temperature associated with the waning of hydrothermal activity and would have been only related indirectly to water/rock ratios.

\section{Acknowledgments}

Funding for this study was provided by the Geological Society of America, a Rackham dissertation/thesis grant, and a grant from the Scott Turner Fund at the University of Michigan. The wealth of knowledge of various aspects of the geology of the Bayhorse district made available by S. Warren Hobbs, Dooley P. Wheeler, Jr., and Patrick DeWilliam is greatly appreciated. Ronald G. Worl was instrumental in organizing this project. The Umont Mining and Inspiration Copper companies granted access to their properties and drill core. Michael Wasserman, Jeffrey Deen, and Carol Ghent generously assisted with the stable isotope analyses. Stimulating discussions and/or thorough reviews of earlier versions of this manuscript were provided by W. C. Shanks III, N. K. Foley, W. C. Kelly, S. E. Kesler, R. M. Kettler, and three Economic Geology reviewers. Sophia V. Loferski highlighted the final stages of the preparation of this manuscript.

April 26, November 26, 1991

\section{REFERENCES}

Barnes, H. L., 1979, Solubilities of ore minerals, in Barnes, H. L., ed., Geochemistry of hydrothermal ore deposits: New York, Wiley Intersci., p. 404-460.

Billings, G. K., and Williams, H. H., 1967, Distributions of chlorine in terrestrial rocks (a discussion): Geochim. et Cosmochim. Acta, v. 31, p. 2247.

Bowers, T. S., and Helgeson, H. C., 1983, Calculation of the thermodynamic and geochemical consequences of nonideal mixing in the system $\mathrm{H}_{2} \mathrm{O}-\mathrm{CO}_{2}-\mathrm{NaCl}$ on phase relations in geologic systems: Equation of state for $\mathrm{H}_{2} \mathrm{O}-\mathrm{CO}_{2}-\mathrm{NaCl}$ fluids at high pressures and temperatures: Geochim. et Cosmochim. Acta, v. 47, p. $1247-1275$

Burruss, R., 1981, Analysis of phase equilibria in C-O-H-S fluid inclusions: Mineralog. Assoc. Canada Shortcourse Handbook 6, p. 39-74.

Campbell, A., Rye, D., and Petersen, U., 1984, A hydrogen and oxygen isotope study of the San Cristobal mine, Peru: Implications of the role of low water to rock ratio for the genesis of wolframite deposits: ECON. GEOL., v. 79, p. 1818-1832.

Carothers, W. W., Adami, L. H., and Rosenbauer, R. J., 1988, Experimental oxygen isotope fractionation between siderite- 
water and phosphoric acid liberated $\mathrm{CO}_{2}$-siderite: Geochim. et Cosmochim. Acta, v. 52, p. 2445-2450.

Chambers, A. E., 1966, Geology and mineral deposits of part of the Bayhorse mining district, Custer County, Idaho: Unpub. Ph.D. thesis, Univ. Arizona, 154 p.

Claypool, G. E., Holser, W. T., Kaplan, I. R., Sakai, H., and Zak, I., 1980, The age curves of sulfur and oxygen isotopes in marine sulfate and their mutual interpretations: Chem. Geology, v. 28, p. $199-260$.

Clayton, R. N., and Mayeda, T. K., 1963, The use of bromine pentafluoride in the extraction of oxygen from oxides and silicates for isotopic analysis: Geochim. et Cosmochim. Acta, v. 27, p. 43-52.

Clayton, R. N., O'Neil, J. R., and Mayeda, T. K., 1972, Oxygen isotope fractionation between quartz and water: Jour. Geophys. Research, v. 77, p. 3057-3067.

Collins, P. L. F., 1979, Gas hydrates in $\mathrm{CO}_{2}$-bearing fluid inclusions and the use of freezing data for estimation of salinity: ECON. GEOL., v. 74, p. 1435-1444.

Constantopoulos, J., 1988, Fluid inclusions and rare earth element geochemistry of fluorite from south-central Idaho: ECON. GeOL., v. 83 , p. $626-636$.

Craig, H., 1961, Isotopic variations in meteoric waters: Science, v. 133 , p. $1702-1703$.

Criss, R. E., and Fleck, R. J., 1990, Oxygen isotope map of the giant metamorphic-hydrothermal system around the northern part of the Idaho batholith, U.S.A.: Appl. Geochemistry, v. 5, p. 641-655.

Criss, R. E., and Taylor, H. P., Jr., 1986, Meteoric-hydrothermal systems: Rev. Mineralogy, v. 16, p. 373-424.

Czamanske, G. K., and Rye, R. O., 1974, Experimentally determined sulfur isotope fractionations between sphalerite and galena in the temperature range $600^{\circ}$ to $275^{\circ} \mathrm{C}$ : ECON. GEOL., v. 69 , p. 17-25.

Erwood, R. J., Kesler, S. E., and Cloke, P. L., 1979, Compositionally distinct, saline hydrothermal solutions, Naica mine, Chihuahua, Mexico: ECON. GeOL., v. 74, p. 95-108.

Foley, N. K., Bethke, P. M., and Rye, R. O., 1989, A reinterpretation of the differences in $\delta \mathrm{D}_{\mathrm{H}_{2} \mathrm{O}}$ of inclusion fluids in contemporaneous quartz and sphalerite, Creede mining district, Colorado: A generic problem for shallow orebodies?: ECON. GEOL., v. 84 , p. $1966-1977$.

Godfrey, J. D., 1962, The deuterium content of hydrous minerals from the east-central Sierra Nevada and Yosemite National Park: Geochim. et Cosmochim. Acta, v. 26, p. 1215-1245.

Hoagland, A. D., 1979, Geology of the Bayhorse fluorite deposit, Custer County, Idaho-a discussion: ECON. GEOL., v. 74, p. 164-165.

Hobbs, S. W., 1985a, Precambrian and Paleozoic sedimentary terranes in the Bayhorse area of the Challis quadrangle: U. S. Geol. Survey Bull. 1658, p. 59-68.

$-1985 \mathrm{~b}$, Structural and stratigraphic controls of ore deposits in the Bayhorse area, Idaho: U. S. Geol. Survey Bull. 1658, p. 133140.

Hobbs, S. W., and Hays, W. H., 1990, Ordovician and older rocks of the Bayhorse area, Custer County, Idaho: U. S. Geol. Survey Bull. 1891, 40 p.

Hodges, W. A., 1978, Igneous petrology, structural geology, and mineralization of the central part of the Bayhorse mining district, Custer County, Idaho: Unpub. M.Sc., Oregon State Univ., $310 \mathrm{p}$.

Howe, S. S., and Hall, W. E., 1985, Light-stable isotope characteristics of ore systems in central Idaho: U. S. Geol. Survey Bull. 1658 , p. 183-192.

Irwin, H., Curtis, C., and Coleman, M., 1977, Isotopic evidence for source of diagenetic carbonates formed during burial of organic-rich sediments: Nature, v. 269, p. 209-213.
Keevil, N. B., 1942, Vapor pressures of aqueous solutions at high temperatures: Am. Chem. Soc. Jour., v. 64, p. 841-850.

Kishima, N., and Sakai, H., 1980, Oxygen-18 and deuterium determination on a single water sample of a few milligrams: Anal. Chemistry, v. 52 , p. $356-358$.

Lohmann, K. C., 1988, Geochemical patterns of meteoric diagenetic systems and their application to studies of paleokarst, in James, N. P., and Choquette, P. W., eds., Paleokarst: New York, Springer-Verlag, p. 58-80.

Longstaffe, F. J., 1987, Stable isotope studies of diagenetic processes: Mineralog. Assoc. Canada, Short Course Handbooks, v. 13 , p. $187-257$.

Mabey, D. R., and Webring, M. W., 1985, Regional geophysical studies in the Challis quadrangle: U. S. Geol. Survey Bull. 1658, p. $69-80$.

McCrea, J. M., 1950, The isotopic chemistry of carbonates and a paleotemperature scale: Jour. Chem. Physics, v. 18, p. 849857.

McIntyre, D. H., Hobbs, S. W., Marvin, R. F., and Mehnert, H. H., 1976, Late Cretaceous and Eocene ages for hydrothermal alteration and mineralization, Bayhorse district and vicinity, Custer County, Idaho: Isochron/West, no. 16, p. 11-12.

Montoya, J. W., and Hemley, J. J., 1975, Activity relations and stabilities in alkali feldspar and mica alteration reactions: EcoN. GEOL., v. 70, p. 577-583.

Northrop, D. A., and Clayton, R. N., 1966, Oxygen isotope fractionations in systems containing dolomite: Jour. Geology, v. 74, p. 174-196.

Ohmoto, H., 1972, Systematics of sulfur and carbon isotopes in hydrothermal ore deposits: ECON. GEOL., v. 67, p. 551-578.

1986, Stable isotope geochemistry of ore deposits: Rev. Mineralogy, v. 16 , p. $491-559$.

Ohmoto, H., and Rye, R. O., 1974, Hydrogen and oxygen isotopic compositions of fluid inclusions in the Kuroko deposits, Japan: ECON. GEOL., v. 69, p. 947-953.

- 1979, Isotopes of sulfur and carbon, in Barnes, H. L., ed., Geochemistry of hydrothermal ore deposits: New York, Wiley Intersci., p. 509-567.

Ohmoto, H., Mizukami, M., Drummond, S. E., Eldridge, C. S., Pisutha-Arnond, V., and Lenagh, T. C., 1983, Chemical processes of Kuroko formation: ECON. GEOL. MON. 5, p. 570-604.

O'Neil, J. R., and Taylor, H. P., Jr., 1969, Oxygen isotope equilibrium between muscovite and water: Jour. Geophys. Research, v. 74 , p. 6012-6022.

Potter, R. W., II, 1977, Pressure corrections for fluid-inclusion homogenization temperatures based on the volumetric properties of the system $\mathrm{NaCl}_{2} \mathrm{H}_{2} \mathrm{O}:$ U. S. Geol. Survey Jour. Research, v. 5, p. 603-607.

Potter, R. W., II, Clynne, M. A., and Brown, D. L., 1978, Freezing point depression of aqueous sodium chloride solutions: ECON. GEOL., v. 73, p. 284-285.

Roedder, E., 1979, Fluid inclusions as samples of ore fluids, in Barnes, H. L., ed., Geochemistry of hydrothermal ore deposits: New York, Wiley Intersci., p. 684-737.

1984, Fluid inclusions: Rev. Mineralogy, v. 12, 644 p.

Ross, C. P., 1937, Geology and ore deposits of the Bayhorse region, Custer County, Idaho: U. S. Geol. Survey Bull. 877, 161 p.

Rye, R. O., 1966, The carbon, hydrogen, and oxygen isotopic composition of the hydrothermal fluids responsible for the lead-zinc deposits at Providencia, Zacatecas, Mexico: ECON. GEOL., v. 61, p. 1399-1427.

Seal, R. R., II, 1989, Relationship of water-rock interactions to base- and precious-metal mineralization, Bayhorse district, Idaho: Unpub. Ph.D. thesis, Univ. Michigan, 273 p.

Seal, R. R., II, and Rye, R. O., 1991, Fluid inclusions in ore deposits as large-scale continental paleoclimate indicators: An example from the Eocene of Idaho [abs.]: Chapman Conf. Conti- 
nental Isotopic Indicators of Climate, Jackson, Wyoming, June 1991, Abstracts and Proceedings, p. 16.

Seal, R. R., II, Essene, E. J., and Kelly, W. C., 1990, Tetrahedrite and tennantite: Evaluation of thermodynamic data and phase equilibria: Canadian Mineralogist, v. 28, p. 725-738.

Sheppard, S. M. F., Nielsen, R. L., and Taylor, H. P., Jr., 1969 Oxygen and hydrogen isotope ratios of clay minerals from porphyry copper deposits: ECON. GEOL., v. 66, p. 755-777.

Snyder, K. D., 1978, The geology of the Bayhorse fluorite deposit, Custer County, Idaho: ECON. GEOL., v. 73, p. 207-214.

Sterner, S. M., and Bodnar, R. J., 1984, Synthetic fluid inclusions in natural quartz I: Compositional types synthesized and applications to experimental petrology: Geochim. et Cosmochim. Acta, v. 48, p. 2659-2668.

Suzuoki, T., and Epstein, S., 1976, Hydrogen isotope fractionation between $\mathrm{OH}$-bearing minerals and water: Geochim. et Cosmochim. Acta, v. 40, p. 1229-1240.
Takenouchi, S., and Kennedy, G. C., 1965, The solubility of carbon dioxide in $\mathrm{NaCl}$ solutions at high temperatures and pressures: Am. Jour. Sci., v. 263, p. 445-454.

Taylor, H. P., Jr., 1979, Oxygen and hydrogen isotope relationships in hydrothermal mineral deposits, in Barnes, H. L., ed., Geochemistry of hydrothermal mineral deposits: New York, Wiley Intersci., p. 236-277.

Truesdell, A. H., 1984, Chemical geothermometers for geothermal exploration: Rev. Econ. Geology, v. 1, p. 31-44.

Wedepohl, K. H., 1971, Environmental influences on the chemical composition of shales and clays: Physics Chemistry Earth, v. 8, p. 307-333.

White, D. E., 1980, Active geothermal systems and hydrothermal ore deposits: ECON. GEOL. 75TH ANNIV. VoL., p. 392-423.

Wones, D. R., 1989, Significance of the assemblage titanite + magnetite + quartz in granitic rocks: Am. Mineralogist, v. 74, p. 744-749. 